\title{
National Railroad Passenger Corporation v. Morgan: A Problematic Formulation of the Continuing Violation Theory
}

\author{
Vincent Cheng $\dagger$
}

TABLE OF CONTENTS

Introduction.

I. National Railroad Passenger Corporation v. Morgan:

A Statement of the Case.

A. The Facts

B. The Ninth Circuit Decision: The "Sufficient Relation"

Standard Governs Continuing Violations.

C. The Supreme Court Decision: An All-or-Nothing View of the Continuing Violation Theory.....

1. The Majority Opinion.

2. Justice O'Connor's Concurring and Dissenting Opinion.

II. Legal Background: Pattern-or-Practice Cases, Congressional Intent, and the Pre-Morgan Circuit Courts

A. The Nature of Pattern-or-Practice Cases................................ 1432

B. Congressional Intent to Eradicate Pattern-or-Practice

Discrimination

C. The Pre-Morgan Circuits' Pattern-or-Practice Doctrine

1. The Ninth Circuit's Ongoing Policy Standard

2. Other Pre-Morgan Circuits.

D. The Relationship Between Continuing Violations and

Discrimination in Promotions

III. Pattern-or-Practice Cases in the Post-Morgan Era

Copyright $\odot 2003$ California Law Review, Inc. California Law Review, Inc. (CLR) is a California nonprofit corporation. CLR and the authors are solely responsible for the content of their publications.

$\dagger \quad$ J.D., School of Law, University of California, Berkeley (Boalt Hall), 2003; B.A., University of California, Berkeley (Mathematics and Philosophy). Special thanks to Professor Linda Krieger, Donna Maeda, and the members of the California Law Review, particularly Sarah Abbott and Jean Galbraith, for their encouragement and helpful suggestions. 
A. Morgan's Doctrinal Distinction between Discrete Acts and Repeated Conduct ...................................................... 1442

1. Morgan as a Judicial Compromise ................................... 1442

2. The (Un)tenability of Morgan's Doctrinal Distinction ...... 1445

a. Morgan's Mischaracterization of Discriminatory Promotion Practices ..................................................... 1445

b. Morgan's Doctrinal Incoherence .............................. 1447

B. The Application of Morgan to Pattern-or-Practice Cases? ...... I450

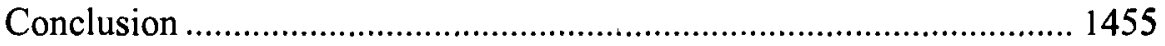




\title{
National Railroad Passenger Corporation v. Morgan: A Problematic Formulation of the Continuing Violation Theory
}

\author{
Vincent Cheng
}

\section{INTRODUCTION}

Congress passed Title VII of the Civil Rights Act of 1964 largely to tackle systematic practices of employment discrimination. ${ }^{1}$ As one of the most effective federal antidiscrimination statutes in employment discrimination law, Title VII prohibits an employer from discriminating against an employee because of the employee's race, color, religion, sex, or national origin. ${ }^{2}$ A person claiming to be aggrieved by an alleged act of employment discrimination must file a charge with the Equal Employment Opportunity Commission (EEOC) within a 180-day or 300-day period, depending on whether the state has its own agcncy authorized to contest the challenged practice. ${ }^{3}$

Considered by judges and legal scholars to be the most muddled doctrine in employment discrimination law, ${ }^{4}$ the "continuing violation" theory

1. See, e.g., McDonnell Douglas Corp. v. Green, 411 U.S. 792, 800 (1973) ("The language of Title VII makes plain the purpose of Congress to assure equality of employment opportunities and to eliminate thosc discriminatory practices and devices which havc fostered racially stratified job environments to the disadvantage of minority citizens."); Griggs v. Duke Power Co., 401 U.S. 424, 429-30 (I97I) ("The objective of Congress in the enactment of Title VII ... was to achieve equality of employment opportunities and remove barriers that have operated in the past to favor an identifiable group of white employees over other employees."). For accounts of the legislative history of Title VII of the Civil Rights Act of 1964, see Norbert Schlei, Foreword to I Barbara Lindemann Schlei \& Paul Grossman, Employment Discrimination Law, at xi-xviii (2d ed. 1983); Robert Beiton, $A$ Comparative Review of Public and Private Enforcement of Title VII of the Civil Rights Act of I964, 3I VAND. L. Rev. 905, 908-09 (1978); Francis Vaas, Title VII: Legislative History, 7 B.C. InDus. \& Com. L. Rev. 431 (1966).

2. See Title VII of the Civil Rights Act of $1964 \S 703,42$ U.S.C. $\S 2000 \mathrm{c}-2(2000) . \S 2000 \mathrm{e}-$ 2(a) provides:

It shall be an unlawful employment practice for an employer-

(l) to fail or refuse to hire or to discharge any individual, or otherwise to discriminate against any individual with respect to his compensation, terms, conditions, or privileges of employment, because of such individual's racc, color, religion, sex, or national origin ....

3. Title VII of the Civil Rights Act of $1964 \S 706,42$ U.S.C. $\S 2000 \mathrm{e}-5$ (2000).

4. See 2 Barbara lindemann \& Paul Grossman, Employment Discrimination Law I35] (3d ed. 1996) ("The cascs discussing 'continuing violations' arc impossible to reconcile."); see also Galloway v. Gen. Motors Serv. Parts Operations, 78 F.3d I164, 1165 (7th Cir. 1996) ("The question 
is a procedural theory that provides an exception to the statute of limitations requirement for timely charge filing. The theory allows courts to toll or extend the limitations period so that plaintiffs may recover in part based on defendants' discriminatory conduct occurring before that period. ${ }^{5} \mathrm{~A}$ continuing violation encompasses a defendant's discriminatory acts occurring before the limitations period on the theory that they were part of a related course of conduct that continued into the charge-filing period. Courts applying the continuing violation theory have tolled or extended the 180-day or 300-day limitations period to allow aggrieved parties to sue based on discriminatory employment practiees occurring prior to and during the charge-filing period. ${ }^{6}$

Therefore, the procedural theory has played a pivotal role in eliminating discrimination in the workplace by permitting many individual and class action Title VII lawsuits that would have otherwise been time-barred to go forward. ${ }^{7}$ Additionally, since Title VII allows recovery of back pay up to two years prior to the charge-filing date, ${ }^{8}$ plaintiffs who have

when conduct occurring outside the statute of limitations may, by virtue of its link with recent conduct, be made a basis for a legal claim is a vexing one ...."); Berry v. Bd. of Supervisors of La. State Univ., 715 F.2d 971, 979 (5th Cir. 1983) (noting that "the precise contours and theoretical bases" of the continuing violation theory "are at best unclear"); Thelma Crivens, The Continuing Violation Theory and Systemic Discrimination: In Search of a Judicial Standard for Timely Filing, 41 VAND. L. Rev. 1171,1172 (1988) (describing continuing violation theory as "one of the most confusing theories in employment discrimination law"); Douglas Laycock, Continuing Violations, Disparate Impact in Compensation, and Other Title VII Issues, 49 LAW \& CoNTEMP. ProBs. 53, $55-59$ (1986) (explaining the various sources behind this confusion).

5. See Douglas v. Cal. Dep't of Youth Auth., 271 F.3d 812, 822 (9th Cir. 2001) ("The continuing violations doctrine extends the accrual of [an employment discrimination] claim...."); Berry, 715 F.2d at 979 (understanding the continuing violation theory to be one that "relieves a plaintiff who makes [an employment discrimination claim] from the burden of proving that the entire violation occurred within the actionable period"); Crivens, supra note 4, at 1172.

6. See, e.g., Fitzgerald v. Henderson, 251 F.3d 345, 364 (2d Cir. 2001) (holding that the plaintiff's assertions of escalating sexual harassment presented an adequate basis for application of the continuing violation theory); Reed v. Lockheed Aircraft Corp., 613 F.2d 757, 761-62 (9th Cir. 1980) (holding that a genuine issue of material fact existed as to whether the employer defendant "maintained a continuous policy of favoring males in selecting employees for promotions and for training programs").

7. Cf. Crivens, supra note 4 , at 1172 (stating that individual as well as class action lawsuits have resulted in the elimination of many discriminatory practices by employers, much of which depended on courts' interpretation of the nature and seope of the continuing violation theory).

8. See 42 U.S.C. $\S 2000 \mathrm{e}-5(\mathrm{~g})(1)(2000)$. Title V1l's allowance for two-year back pay recovery, coupled with the fact that a Title Vll plaintiff must file a charge with the EEOC within 180 or 300 days, has led courts and legal scholars to conclude that Congress anticipated a continuing violation theory. See, e.g., Sabree v. United Bhd. of Carpenters Local No. 33, 921 F.2d 396, 401 (1st Cir. 1990) ("By allowing for the possibility of recovering back pay for over a year prior to the 300 day filing period, Congress must have envisioned continuing remediable violations that existed prior to the running of the period.") (quotations omitted); Michael Zimmer ET al., CASES and Materials on EMPloyment Discrimination 942 (5th ed. 2000). Furthermore, when amending Title Vll in 1972, Congress was clearly aware of discriminatory practices that are continuing in nature. According to the Senate Report to the amended Title Vll: 
successfully established continuing violations of their rights under Title VII may obtain back pay for a period longer than the 180 or 300 day charge-filing period. ${ }^{9}$

Prior to National Railroad Passenger Corp. v. Morgan,$^{10}$ where the Supreme Court addressed for the first time the scope and application of the continuing violation theory, the Court's employment discrimination law jurisprudence not only provided scant guidance on, but also caused confusion about, the procedural theory. ${ }^{11}$ The paucity and inadequacy of judicial

\footnotetext{
Existing case law which was [sic] determined that certain types of violations are continuing in nature, thereby measuring the running of the required time period from the last occurrence of the discrimination and not from the first occurrence is continued, and other interpretations of the courts maximizing the coverage of the law are not affected. It is intended by expanding the time period for filing charges ... that aggrieved individuals, who frequently are untrained laymen and who arc not always aware of the discrimination which is practiced against them, should be given a greater opportunity to prepare their charges and file their complaints and that existant but undiscovered acts of discrimination should not escape the effect of the law through a procedural oversight.
}

Staff of Sen. Comm. on Labor and Public Welfare, 92d Cong., Legislative History of the Equal Employment Opportunity Act of 1972 (H.R. 1746, P.L. 92-261) 1846 (Comm. Print 1972) [hereinafter "1972 LegisLATIVE History"].

9. Sabree, 921 F.2d at 400-01; Berry, 715 F.2d at 980 ("[O]nce having shown discrimination continuing into the actionable period, ... the plaintiffs may also recover for portions of the persistent process of illegal discrimination that antedated the limitations period.") (citations and quotations omitted).

10. 536 U.S. 101 (2002).

11. See Bazemore v. Friday, 478 U.S. 385, 395 (1986); Del. State Coll. v. Ricks, 449 U.S. 250 (1980); United Air Lines, Inc. v. Evans, 431 U.S. 553 (1977). Although the pre-Morgan Supreme Court made attempts to spell out the confines of the continuing violation theory, the Court never promulgated a distinct set of substantive rules as guideposts for lower courts encountering continuing violation suits. The confusion began with United Air Lines, Inc. v. Evans, in which the plaintiff was forced to resign in 1968 because of United's "no marriage" rule but was rehired in 1972 after the rule was held violative of Title VII and thus was no longer in place. 431 U.S. at 558. Rejecting the plaintiff's contention that United unlawfully denied the plaintiff her pre-1972 seniority, the Evans Court declared that present effects of past discrimination are not actionable and emphasized that an inquiry concerning continuing violation should focus on the question of whether any present violation exists. Id.

In Delaware State College v. Ricks, where a black professor alleged that the school's decision to deny him tenure was based on his national origin, the Court claimed that for the purpose of timely charge filing, the statute of limitations began to run when he was put on notice that he had been denied tenure-not when the plaintiff's employment ended a year after he had learned of the tenure decision. 449 U.S. at $252-54,259$. In a line of reasoning parallel to that in Evans, the Ricks Court added, "the proper focus is upon the timc of the discriminatory acts, not upon the time at which the consequences of the acts became most painful." Id. at 258 (quoting Abramson v. Univ. of Haw., 594 F.2d 202, 209 (1979) (emphasis added in Ricks)). Evans, together with Ricks, created the false impression in some lower courts that the Supreme Court had abrogated the entire continuing violation theory. See I Lindemann \& Grossman, supra note 4, at 1352 (eiting Kyriazi v. Western Elec. Co., 461 F. Supp. 894, 901 (D.N.J. 1978)). However, the two decisions merely stated the outer limit of the procedural theory-that is, the restrictive rule that absent any present violation, present effects of past discrimination are not actionable.

Finally, in Bazemore v. Friday, a case involving a racially discriminatory salary system instituted prior to the passage of Title VIl, the Court held that "[e]ach week's paycheck that delivers less to a black than to a similarly situated white is a wrong actionable under Title VIl." 478 U.S. at 395. To reconcile its holding with Evans, the Bazemore Court distinguished Bazemore from Evans on the basis 
guidance from the Supreme Court contributed to divergent interpretations of the procedural theory among the courts of appeals.

A brief survey of the pre-Morgan circuits' views on serial discriminatory acts provides a glimpse of the lack of uniformity among, and sometimes even within, these circuits regarding the meaning of the continuing violation theory. Pre-Morgan circuit courts generally followed one of two approaches for determining the circumstances under which a series of alleged discriminatory acts constitute a continuing violation.

The first approach, announced by the Fifth Circuit in Berry v. Board of Supervisors, ${ }^{12}$ consisted of three factors the court deemed relevant to the determination of whether alleged discriminatory acts are closely related enough to satisfy the continuing violation theory. The first factor, subject matter, requires courts to ask whether the alleged acts involve the same type of discrimination. The second factor, frequency, inquires whether the alleged acts are recurring or isolated occurrences of discrimination. The third factor, and most important according to the court, examines whether an alleged act has reached a "degree of permanence" that "should trigger an employee's awareness of and duty to assert his or her rights." 13 This three-prong test thus focused not only on the relatedness and repeated nature of the alleged acts but also on whether a reasonable person in the plaintiff employee's position should have asserted his or her rights earlier. Other circuit courts, including the First Circuit, ${ }^{14}$ the Third Circuit, ${ }^{15}$ the Seventh Circuit, ${ }^{16}$ and the Tenth Circuit, ${ }^{17}$ largely appropriated this Berry test.

By contrast, the pre-Morgan Ninth Circuit applied a "sufficient relation" standard for determining continuing violations. A plaintiff wishing to establish a continuing violation could prove a "serial violation" by showing that the alleged acts occurring prior to the limitations period were

that while in Evans United had terminated its discriminatory policy by the time the plaintiff brought suit, the employer in Bazemore had not. Id. at 396 n.6.

12. 715 F.2d 971 (5th Cir. 1983).

13. Id. at 981 .

14. See, e.g., Sabree v. United Bhd. of Carpenters Local No. 33, 921 F.2d 396, 402 (1st Cir. 1990) (considering the Berry test's degree of permanence factor to be the most important inquiry for determining the relationship between alleged discriminatory acts).

15. See, e.g., West v. Philadelphia Elec. Co., 45 F.3d 744, 755 (3d Cir. 1995) (finding the Berry test helpful for determining the existence of a continuing violation).

16. See, e.g., Galloway v. Gen. Motors Serv. Parts Operations, 78 F.3d 1164, 1167 (7th Cir. 1996) ("[T]he plaintiff may not base her... suit on conduct that occurred outside the statute of limitations unless it would have been unreasonable to expect the plaintiff to sue before the statute ran on that conduct...."); Selan v. Kiley, 969 F.2d 560, 566-67 (7th Cir. 1992) (applying the Fifth Circuit's Berry test to the plaintiff's claim regarding transfer and promotion).

17. See, e.g., Mascheroni v. Bd. of Regents, 28 F.3d 1554, 1561 (10th Cir. 1994) (stating that an inquiry for determining whether the plaintiff's alleged incidents constitute a series of related discriminatory acts must consider factors such as subject matter, frequency, and permanence). 
sufficiently related to those occurring within the period. ${ }^{18}$ While the alleged incidents could not be of an isolated, sporadic, or discrete nature, ${ }^{19}$ the Ninth Circuit only required that they be "plausibly related" in order to meet the sufficient relation standard. ${ }^{20}$ The inquiry focused on whether "there is a common type of discrimination; such as sexual or gender-based [or racial] harassment, or if there is a common kind of employment action, such as repeated denial of promotion." 21 The Ninth Circuit refused to apply the Fifth Circuit's Berry test and specifically precluded the rigid notice requirement, as embodied by the test's "degree of pcrmanence" factor, from its formulation of the continuing violation theory. ${ }^{22}$ Although circuits were not as receptive to the Ninth Circuit's sufficient relation standard as they were to the Fifth Circuit's Berry test, the First Circuit formulated a "serial violation" theory parallel to the Ninth Circuit's sufficient relation standard ${ }^{23}$ despite the fact that it also approved of the Berry test. ${ }^{24}$

In National Railroad Passenger Corp. v. Morgan, the Supreme Court addressed for the first time under what circumstances a Title VII plaintiff may file suit based on incidents outside the charge-filing period. In Morgan, all nine justices agreed that discrete discriminatory and retaliatory acts that fall outside Title VII's statute of limitations period are timebarred, rejecting the application of the continuing violation theory to such

18. See Anderson v. Reno, 190 F.3d 930, 936-37 (9th Cir. 1999); Green v. L.A. County Superintendent of Sch., 883 F.2d 1472, 1480-81 (9th Cir. 1989).

19. See Draper v. Coeur Rochester, Inc., 147 F.3d 1104, I 107-10 (9th Cir. 1998).

20. Sosa v. Hiraoka, 920 F.2d 1451, 1456 (9th Cir. 1990) (finding a sufficient relationship where the alleged acts were "plausibly related as acts of discrimination against [the plaintiff] because of his identification as a Mexican-American").

21. See Fielder v. UAL Corp., 218 F.3d 973, 986 (9th Cir. 2000) ("Every incident of discrimination before the limitations period need not be of the same type, so long as there is a corresponding type of discrimination within the period.").

22. See id. at 988 (holding that the continuing violation theory applied to the pre-limitations incidents alleged in the plaintiff's sexual harassment claim even though a reasonable person in the plaintiff's situation would have been put on notice by the pre-limitations incidents that her rights werc violated); Anderson, 190 F.3d at 936-37 (allowing the plaintiff to sue on harassment incidents stretching back to roughly eight years prior to the filing of her EEOC charge); see also Morgan v. Nat'1 R.R. Passenger Corp., 232 F.3d 1008, 1015 (9th Cir. 2000) (affirming the Ninth Circuit's rejection of applying the Fifth Circuit's Berry test to serial violations).

23. See, e.g., Jensen v. Frank, 912 F.2d 517, 522 (Ist Cir. 1990) (claiming that a serial violation consists of discriminatory acts emanating from the same discriminatory animus). Jensen looked to the Ninth Circuit's statement that a serial violation contemplates "demonstrating a series of related acts against a single individual." Green, 883 F.2d at 1480 . On the other hand, the California Supreme Court refused to follow the Ninth Circuit's sufficient relation standard and adopted a modified version of the Fifth Circuit's Berry test. See Richards v. CH2M Hill, Inc., 29 P.3d 175, 190 (Cal. 2001) (holding that the modified version of the permanence factor means that "an employer's statements and actions make clear to a reasonable employee that any further efforts at informal conciliation to obtain reasonable accommodation or end harassment will be futile").

24. See Sabree v. United Bhd. of Carpenters Local No. 33, 921 F.2d 396, 402 (1st Cir. 1990) ("The Fifth Cireuit has suggested a number of factors, including whether 'the act [has] the degree of permanence which should trigger an employee's awareness and duty to assert his or her rights.") (quoting Berry v. Bd. of Supervisors of La. State Univ., 715 F.2d 971, 981 (5th Cir. 1983)). 
acts. ${ }^{25} \mathrm{~A}$ divided Court also held that the continuing violation theory is applicable to hostile work environment claims because such claims allege a series of incidents, some of which may not be independently actionable, which collectively create an offensive or intimating working atmosphere. ${ }^{26}$

This Casenote analyzes Morgan both in light of the pre-Morgan disagreement among circuits over the meaning and scope of the continuing violation theory for serial violations and pattern-or-practice violations, ${ }^{27}$ and also against the backdrop of clear congressional intent to eradicate systemic discrimination and provide make-whole relief. It observes that Morgan represents a shortsighted judicial compromise between employers' worries over defending claims potentially amounting to liability for years of violation and employees' interests in seeking redress for continuing violations in the workplace.

This Casenote claims that neither Morgan's discrete acts rule nor its hostile work environment rule provides an appropriate framework within which to analyze pattern-or-practice claims. Specifically, in light of postMorgan lower court decisions, this Casenote further argues that while Morgan was silent on pattern-or-practice claims, the conceptual framework adopted by the compromised Morgan Court will likely mislead some lower courts into a construction of the continuing violation theory that would deprive plaintiffs of the strategic benefits of filing pattern-or-practice claims. This Casenote contends that lower courts confronted with pattcrn-orpracticc claims need not follow Morgan and should instead adopt a construction of the procedural theory that furthers the substantivc goals of Title VII.

Part I discusses the Ninth Circuit and Supreme Court decisions in Morgan. Part Il examines the congressional intent of eradicating systemic discrimination and reviews the pre-Morgan circuits' application of the continuing violation theory to pattern-or-practice litigation. Part III argues that the all-or-nothing doctrinal distinction between discrete acts and repeated

25. 536 U.S. 101, 105 (2002).

26. Id. at 114. Hostile work environment harassment involves situations in which the plaintiff, while not necessarily having suffered any dircet economic or psychological harm, has been subjected to an intimidating or offensive work environment, which so alters the plaintiff's working conditions as to violate Title V1l. Courts have long recognized harassment claims based not only on sex, but also on race, national origin, and religion. See id. at 116.

One critical element of a prima facie case of hostile work environment is the severity and pervasiveness of the effects that the harassing conduct creates to alter the plaintiff's employment conditions, even without tangible effects on the plaintiff's job performance or psychological wellbeing. See Harris v. Forklift Sys., Inc., 510 U.S. 17, $21-22$ (1993). Specifically, the "“[m]cre utterance of an ... epithet which engenders offensive feelings in a employee' ... does not sufficiently affect the conditions of employment to implicate Title VII." Id. at 21 (quoting Meritor Sav. Bank v. Vinson, 477 U.S. 57, 65 (1986)).

27. A pattern-or-practice claim generally involves an allegation against an employer for its maintenance of a company-widc discriminatory employment system. See infra Part II.A for a more dctailed account of the nature of pattern-or-practice cases. 
conduct that the Morgan majority adopted to justify its holdings fails to adequately reflect the empirical nature of employment discrimination, and suggests that lower courts adopt a case-by-case approach towards plaintiffs alleging "discrete" discriminatory acts. Through an analysis of a Ninth Circuit decision interpreting Morgan and a discussion of other postMorgan lower court decisions, this Part further argues that the Morgan Court's conceptual framework encourages lower courts to apply the continuing violation theory to pattern-or-practice cases in a way that defeats the purposes of initiating those lawsuits in the first place. Accordingly, this Part suggests that courts should refrain from adopting Morgan's conceptual framework in pattern-or-practice cases and instead construe the continuing violation theory in a manner consistent with the congressional intent of eliminating systemic discrimination and providing make-whole relief to victims of discrimination.

\section{I \\ NATIONAL RAILROAD PASSENGER CORPORATION V. MORGAN: STATEMENT OF THE CASE}

\section{A. The Facts}

Abner Morgan, an African American male, worked for the National Railroad Passenger Corporation ("Amtrak") from August 1990 to March $1995 .{ }^{28}$ On February 27, 1995, prior to his termination on March 3, 1995, Morgan filed a charge of racial discrimination and retaliation ${ }^{29}$ against Amtrak with the EEOC and cross-filed with the California Department of Fair Employment and Housing. ${ }^{30}$

Morgan alleged not only a number of discriminatory incidents that had occurred within the 300-day charge-filing period, but also many discriminatory events that took place before that period. According to Morgan, his refusal to attend a meeting without union representation resulted in his termination in February 1991, which Amtrak later reduced to a ten-day suspension after Morgan filed a grievance. ${ }^{31}$

Morgan also claimed that prior to and within the limitations period, he was repeatedly denied access to professional training. For example, Amtrak removed his name from the list of employee trainees in May

28. Morgan v. Nat'I R.R. Passenger Corp., 232 F.3d 1008, 1010-13 (9th Cir. 2000).

29. Section 704(a) of Title VII protects employees who oppose discrimination or participate in government investigations of discrimination from retaliation by their employers. 42 U.S.C. $\S 2000 \mathrm{e}-$ 3(a) (2000). To demonstrate a violation of $\S 704(a)$, a plaintiff usually needs to establish (I) that the plaintiff engaged in statutorily protected opposition or participation; (2) that the plaintiff has suffered an adverse employment action; and (3) that there is a causal connection between the statutorily protected expression and the adverse employment action. See 1 Lindemann \& Grossman, supra note 4 , at 672 .

30. Morgan v. Nat'l R.R. Passenger Corp., 232 F.3d at 1014.

31. Id. at 1011 . 
$1993,{ }^{32}$ and cancelled his scheduled training in December 1993 and again in October 1994 without providing any explanation. ${ }^{33}$ According to Morgan, when he asked to participate in an apprenticeship program in August 1991, his supervisor told him that he "stood a snowball's chance in hell of becoming an electrician." ${ }^{34}$

Morgan also claimed that he was repeatedly subjected to unwarranted disciplinary actions before and during the limitations period. For example, his supervisors wrote him up for helping a coworker in October $1991^{35}$ and for failing to complete tasks that were outside his normal job responsibilities in December 1992. ${ }^{36}$ 1n September 1994, Morgan was suspended for turning over unfinished work to the next shift, a common practice at Amtrak, ${ }^{37}$ and again in February 1995 after his supervisor "yelled at Morgan to get his 'black ass' into the office," an order which Morgan refused to follow. ${ }^{38}$

On numerous occasions, Morgan sought improvement of his employment conditions by filing complaints with Amtrak's Equal Employment Office (EEO).$^{39}$ Morgan received no response from Amtrak ${ }^{40}$ and was instead subjected to a barrage of adverse employment actions. In addition to his charges of racial discrimination and retaliation, Morgan made a hostile work environment claim, alleging that, throughout his employment with Amtrak, his supervisors had used racial epithets, made negative comments about African Americans' supervisory ability, and performed racially derogatory acts. ${ }^{41}$

After receiving his "Notice of Right to Sue" from the EEOC, Morgan filed suit against Amtrak in federal district court on October 2, $1996,{ }^{43}$ alleging that from the beginning of his employment with Amtrak, he had been subjected to discriminatory and retaliatory acts and endured a

32. Id. at 1012 .

33. Id. at 1013 .

34. Id. at 1011 .

35. Id.

36. Id. at 1012 .

37. Id. at 1013 .

38. Id.

39. Id. at 1011-13 (noting that Morgan filed complaints with the EEO in October 1991, May 1993, October 1993, and October 1994).

40. Id.

41. Id. at 1013 .

42. According to EEOC guidelines, the EEOC must issue a notice of right to sue letter to the charging party when the EEOC finds no reasonable cause, fails in its conciliation attempt, or does not sue the complaint respondent. 29 C.F.R. $\S \S 1601.19$ (a) \& 1601.28(b) (2002). The charging party may also demand the notice of right to sue letter beforc the completion of the administrative process. 29 C.F.R. $\$ 1601.28(\mathrm{a})(1)-(2)$, (d). Upon receipt of the letter, the charging party has ninety days to bring an action in federal or state court. 42 U.S.C. $\S 2000 \mathrm{e}-5(\mathrm{f})(1)(2000)$. Thus, while filing a charge with the EEOC is a prerequisite to any Title VII suit, exhaustion of agency remedies is not required, contrary to prevailing administrative principles.

43. Morgan v. Nat'l R.R. Passenger Corp., 232 F.3d at 1014. 
racially hostile work environment. ${ }^{44}$ On September 11,1998 , the United States District Court for the Northern District of California granted Amtrak's summary judgment motion in part, holding that Amtrak could not be liable for incidents that occurred prior to May 3, 1994, the beginning of the 300-day charge-filing period. ${ }^{45}$ Specifically, the district court adopted the Seventh Circuit's construction of the continuing violation theory ${ }^{46}$ according to which a court may toll the statute of limitations only when "it would have been unreasonable to expect the plaintiff to sue before the statute ran on that conduct." 47 Since the district court found that Morgan believed he was being discriminated against during each of the allegedly racially motivated incidents, it would not be unreasonable to expect him to have filed an EEOC charge on those acts before the limitations period ran on them. ${ }^{48}$ On November 19,1998 , a jury returned a verdict in Amtrak's favor on Morgan's remaining claims. ${ }^{49}$

\section{B. The Ninth Circuit Decision: The "Sufficient Relation" Standard Governs Continuing Violations}

On appeal, the Ninth Circuit held that the pre-limitations and postlimitations incidents that Morgan alleged were sufficiently related to invoke the continuing violation theory. ${ }^{50}$ Relying on its previous articulation of the continuing violation theory, the Ninth Circuit stated that a plaintiff can establish a continuing violation that imposes liability based on conduct occurring outside the limitations period in one of two ways. First, the plaintiff could prove a "serial violation" under its "sufficient relation" standard. ${ }^{51}$ Alternatively, a plaintiff could prove a "systemic violation" by showing that "a systematic policy or practice of discrimination... operated, in part, within the limitations period." 52

The Ninth Circuit concluded that under the sufficient relation standard, Morgan's claims should have survived Amtrak's summary judgment motion. Regarding Morgan's racial discrimination claims, the court considered all the incidents, both prior to and within the limitations period, as well as Morgan's evidence indicating a racially hostile work environment. ${ }^{53}$ It found that the incidents involved similar employment actions and

44. Id. at 1010

45. Id. at 1014 .

46. Id.

47. Id. at 1014-15 (quoting Galloway v. Gen. Motors Serv. Parts Operations, 78 F.3d 1164, 1167 (7th Cir. 1996)).

48. Id. at 1015 .

49. Id. at 1014 .

50. Id. at 1017 .

51. Id. at 1015; see also supra notes 18-23 and accompanying text.

52. Morgan v. Nat'1 R.R. Passenger Corp., 232 F.3d at 1015-16; see also infra notes 103-08 and accompanying text.

53. Morgan v. Nat'1 R.R. Passenger Corp., 232 F.3d at 1016. 
the same core group of supervisors. ${ }^{54}$ In considering Morgan's retaliation claims, the court took into account Morgan's complaints filed with Amtrak's EEO, the absence of any official response from Amtrak, and the disciplinary actions imposed shortly after he filed each EEO complaint. ${ }^{55}$ In reviewing Morgan's racially hostile work environment claims, the court again considered the similarity of the employment actions involved in the pre-limitations and post-limitations incidents, the frequency of their occurrence, and the fact that they were perpetrated by the same supervisors. ${ }^{56}$ Under the "totality of the circumstances," the court found that the prelimitations and post-limitations incidents were sufficiently related for all of Morgan's claims. ${ }^{57}$

The Ninth Circuit thus held that the district court erred in granting a partial summary judgment exempting Amtrak from liability for prelimitations conduct ${ }^{58}$ It also concluded that the district court should have presented the pre-limitations incidents to the jury, not merely as "background evidence" but also for the purpose of determining Amtrak's liability. ${ }^{59}$ Accordingly, the appellate court vacated the district court's grant of partial summary judgment as well as the judgment on the verdict and granted a new trial on Morgan's claims of discrimination, retaliation, and hostile work environment. ${ }^{60}$

\section{The Supreme Court Decision: An All-or-Nothing View of the Continuing Violation Theory}

\section{The Majority Opinion}

The United States Supreme Court affirmed in part and reversed in part the Ninth Circuit decision, holding that while the continuing violation theory applies to hostile work environment claims, it does not toll the statute of limitations for claims based on discrete discriminatory and retaliatory acts. ${ }^{61}$ Justice Thomas, writing for the majority, announced the Court's first general rule - that "discrete discriminatory [and retaliatory] acts are not actionable if time barred, even when they are related to acts alleged in

54. Id.

55. Id. at 1017 .

56. Id. The court noted that proof of a hostile work environment requires a showing of "a pattern of ongoing and persistent harassment severe enough to alter the conditions of employment." Id. (quoting Draper v. Coeur Rochester, Ine., 174 F.3d 1104, 1108 (9th Cir. 1998)).

57. Id.

58. Id. at 1016.

59. Id. at 1017. The Ninth Circuit noted that the distriet court had excluded important evidence for proof of Morgan's hostile work environment claims and recommended that, on retrial, "the district court, when ruling on admissibility of evidence ... consider all evidence in light of its relevance to whether the defendant's conduct may be considered severe and pervasive." Id. at 1018 .

60. Id. at 1018.

61. Nat'l R.R. Passenger Corp. v. Morgan, 536 U.S. 101, 122 (2002). 
timely filed charges" ${ }^{\prime 62}$ and that "[e]ach discrete discriminatory act starts a new clock for filing charges alleging that act." ${ }^{13}$ The Court stated that it is "easy to identify" discrete acts, which include "termination, failure to promote, denial of transfer, or refusal to hire." ${ }^{\prime 4}$ The majority recognized, on the other hand, that the "very nature [of hostile work environment claims] involves repeated conduct" series of separate acts that collectively constitute one 'unlawful employment practice." ",66

The Court then stated its second general rule-that, for the purposes of determining liability, a court may consider the entire period of the alleged hostile work environment as long as an act contributing to the hostile work environment claim occurs within the limitations period. ${ }^{67}$ The majority opinion was joined by all nine justices with respect to the rule concerning discrete discriminatory and retaliatory acts and by Justices Breyer, Ginsburg, Souter, and Stevens with respect to the rule regarding hostile work environments.

In formulating the rule for discrete acts, the Court identified the operative terms "shall," "after... occurred," and "unlawful employment practice" in the charge-filing provision of Title VII and analyzed (1) what constitutes an "unlawful employment practice," and (2) when that practice has occurred. ${ }^{68}$ The Court first observed that an "unlawful employment practice" within the language of the statute includes numerous discrete acts such as discharge and failure to hire. After reviewing a series of its prior decisions, the Court noticed that it had consistently interpreted the word "practice" to apply to discrete acts and rejected the Ninth Circuit's "sufficient relation" standard. ${ }^{69}$ The Court thus concluded that discrete acts falling outside of Title VII's limitations period are time-barred..$^{70}$ However, the Court qualified its conclusion by stating that untimely discrete acts may be used as background evidence to support timely filed claims and that plaintiffs with time-barred claims could invoke equitable doctrines such as tolling or estoppel. ${ }^{71}$

62. Id. at 113 .

63. Id.

64. Id. at 114 .

65. Id. (citing 1 LindemanN \& Grossman, supra note 4, at 348-49).

66. Id. (quoting 42 U.S.C. $\S 2000 \mathrm{e}-5(\mathrm{e})(1)(2000)$ ).

67. Id.

68. Id. at 109-10. The Court eited its precedent endorsing the view that terms in a statute should bear their "ordinary, contemporary, common meaning." Id. at 109 n.5 (quoting Walters v. Metro. Ed. Enters., Inc., 519 U.S. 202, 207 (1997) (internal quotation omitted)).

69. Id. at 111-13 (citing Bazemore v. Friday, 478 U.S. 385 (1986); Del. State Coll. v. Ricks, 449 U.S. 250 (1980); Elec. Workers v. Robbins \& Myers, Inc., 429 U.S. 229 (1979); United Air Lines, Inc. v. Evans, 431 U.S. $553(1977)$ ).

70. Id.

71. Id. at 113 (citing Zipes v. Trans World Airlines, Inc., 455 U.S. 385, 393 (1982)). Tolling and estoppel are equitable doctrines that, when invoked in Title VIl cases, suspend the running of the 
Importantly, the Court also clarified that its opinion did not address the question of how the continuing violation theory should apply with respect to pattern-or-practice claims, which Morgan did not allege. ${ }^{72}$ Furthermore, since the district court found that Morgan was aware of the discriminatory nature of each alleged incident, the Morgan Court claimed that the case presented no occasion to address the issue whether a discrete unlawful employment practice occurs when the injury takes place or when the plaintiff discovers or reasonably should have discovered the injury. ${ }^{73}$

The Court's analytical approach to hostile work environment claims acknowledged that these claims typically involve unlawful employment practices that occur over an extended period of time, cumulatively causing a hostile work environment. ${ }^{74}$ The Court pointed to its jurisprudence concerning hostile work environment claims in the sexual harassment context, ${ }^{75}$ and clarified that standards for reviewing sexual harassment claims also apply to racial harassment claims. ${ }^{76}$ It then rejected the Seventh Circuit's "reasonableness" standard, which time-barred pre-limitations conduct unless it would have been unreasonable to expect a plaintiff to file a hostile work environment claim prior to the limitations period. ${ }^{77}$ Finally, the majority consoled employers with a panoply of available defenses, including equitable doctrines such as waiver, estoppel, equitable tolling, and laches. ${ }^{78}$

statute of limitations for filing a eharge with the EEOC. See 2 Lindemann \& Grossman, supra note 4, at 1364-66 (stating that one equitable ground for invoking the doetrines is that the employer has misled the plaintiff into believing that thcre is no violation of his or her statutory right, and thereby has caused the plaintiff to miss a charge-filing deadline). The Morgan Court warned that tolling and estoppel should be applied sparingly, as "[p]rocedural requirements established by Congress for gaining access to the federal courts are not to be disregarded by courts out of a vague sympathy for particular litigants." 536 U.S. at 113-14 (citing Baldwin County Welcome Ctr. v. Brown, 466 U.S. 147, 152 (1984)).

72. Morgan, 536 U.S. at 115 n.9 ("We have no oecasion here to consider the timely filing question with respect to 'pattern-or-praetice' claims brought by private litigants as none are at issue here.").

73. Id. at $114 \mathrm{n} .7$

74. Id. at 114 .

75. Id. at 115-16. For example, in Meritor Savings Bank v. Vinson, 477 U.S. 57 (1986), the Court noted that the mere utterance of an epithet which engenders offensive feelings in an employee is not enough to alter the terms and conditions of employment to the degree neeessary to implicate Title VII. 477 U.S. at 67. See also Harris v. Forklift Sys., Inc., 510 U.S. 17, 21 (1993) (claiming that Titlc VII's prohibition against workplaee harassment is not limited to "economic" or "tangible" discrimination).

76. Morgan, 536 U.S. at 116.

77. Id. at $117 \mathrm{n} .11$; see also supra notes $47-48$ and accompanying text.

78. Morgan, 536 U.S. at 121-22 (citing Zipes v. Trans World Airlines, Inc., 455 U.S. 385, 398 (1982)). Laches is an equitable defense, which "may bar a Title VII action if there is an unreasonable and unexcused delay in bringing the action and the defendant has been materially prejudiccd thereby." 2 LiNDEMANN \& GRossman, supra note 4, at 1382 . An employer may also privatcly negotiate a waiver of past Title VII causes of action with its employee, provided that the employee knowingly and voluntarily consents to it. Alexander v. Gardner-Denver Co., 415 U.S. 36, 52 (1974). 
The Court reversed the Ninth Circuit decision regarding Morgan's claims based on pre-limitations discrete discriminatory and retaliatory acts because only those acts that occurred within the 300-day limitations period were actionable. ${ }^{79}$ The Court affirmed the Ninth Circuit decision on Morgan's hostile work environment claim. ${ }^{80}$ It specifically held that the similarity of the employment actions by the same perpetrators, their frequency, and the evidence of racially derogatory actions and language warranted a finding that all the incidents were part of the same actionable hostile work environment. ${ }^{81}$ Accordingly, the Court affirmed in part and reversed in part the Ninth Circuit decision and remanded the case for further proceedings. ${ }^{82}$

\section{Justice O'Connor's Concurring and Dissenting Opinion}

Justice O'Connor's concurring opinion on discrete acts, which Justices Rehnquist and Breyer joined, suggested that some notice requirement should apply to these claims. She argued that a plaintiff should be barred from recovery based on a pre-limitations discrete act only after he or she had or should have had notice of the act. ${ }^{83}$

The dissenting portion of O'Connor's opinion, which Justices Kennedy, Rehnquist, and Scalia joined, would have rejected the continuing violation theory altogether, precluding plaintiffs from recovery for hostile work environment claims based on incidents occurring prior to the limitations period ${ }^{84}$ While the dissent agreed with the majority's characterization of hostile work environments as typically spanning a number of years, it argued that "each day the worker is exposed to the hostile environment may still be treated as a separate 'occurrence."'85 The majority's holding, it argued, would unfairly force employers to defend stale hostile work environment claims dating back many years to a time when employee witnesses might only vaguely recall the incidents or have left the employers' companies. $^{86}$

79. Morgan, 536 U.S. at 114. Those timely alleged discriminatory and retaliatory acts that took place within the 300-day period before February 27, 1995, Morgan's eharge-filing date, included a wrongful suspension and charge for insubordination, a denial of professional training, and a false aceusation of threatening a manager. $I d$.

80. Id. at $120-21$.

81. Id.

82. Id. at 122 .

83. Id. at 123-24. The majority's opinion in Morgan noted that the Court had no occasion to resolve the issue as to whether the statute of limitations begins to run when the injury occurs or when the injury should have been reasonably discovered. See supra note 73 and accompanying text.

84. Morgan, 536 U.S. at 124.

85. Id.

86. Id. at 125-26. 
II

\section{Legal Background: Pattern-or-Practice Cases, Congressional Intent, and the Pre-Morgan Circuit Courts}

As stated in Part I, the Morgan Court was silent with regard to the application of the continuing violation theory to pattern-or-practice cases. Part II first explains the nature of pattern-or-practice cases and illustrates the clear Congressional intent to cradicate pattern-or-practice discrimination. It then examines the pre-Morgan circuits' formulations of the continuing violation theory as applied to pattern-or-practice cases, and ends with a specific discussion of the relationship between continuing violations and failure-to-promote claims. This Part thus lays the groundwork for Part III's analysis of Morgan's implications for future pattern-or-practice cases.

\section{A. The Nature of Pattern-or-Practice Cases}

Employment discrimination claims usually involve allegations of disparate treatment based on a plaintiff's statutorily protected characteristic. Essentially, disparate treatment is different treatment. ${ }^{87}$ Pattern-or-practice cases generally involve class action claims of company-wide disparate treatment. ${ }^{88}$ While amending Title VII in 1972, Congress specifically endorscd the use of class action lawsuits to end pattern-or-practice discrimination, recognizing that many Title VII cases are necessarily class action complaints:

The courts have been particularly cognizant of the fact that claims under Title VII involve the vindication of a major public interest, and that any action under the Act involves considerations beyond those raised by the individual claimant. As a consequence, the leading cases in this area to date have recognized that many Title VII claims are necessarily class action complaints .... ${ }^{89}$

87. See Teamsters v. United States, 431 U.S. 324, 335 n. 15 (1977). The Teamsters Court stated: "Disparate treatment" ... is the most easily understood type of discrimination. The employer simply treats some people less favorably than others because of their race, color, religion, sex, or national origin. Proof of discriminatory motive is critical .... Undoubtedly disparate treatment was the most obvious evil Congress had in mind when it cnacted Title VII. Id.

88. See, e.g., id.; Hazelwood Sch. Dist. v. United States, 433 U.S. 299 (1977). In Teamsters, the government filed a pattern-or-practice class action lawsuit against a company, alleging that blacks and Latinos had been treated less favorably than whites in recruitment, hiring, transfer, and promotion. 431 U.S. at 335. In Hazelwood, the government brought action against a school district, alleging that it had engaged in a pattern or practice of racial discrimination against black teachers in its faculty hiring. 433 U.S. at 299.

89. 1972 Legislative History, supra note 8 , at 1847 . However, the statement may be misleading from a procedural standpoint since an individual litigant who seeks to maintain a class action under Titlc VIl must also satisfy the prcrequisites of numerosity, commonality, typicality, and adequacy of representation set forth in Federal Rule of Civil Procedure 23(a). See, e.g., Gen. Tcl. Co. v. Falcon, 457 U.S. 147, 156 (1982). 
The resort to pattern-or-practice class action suits also comports with courts' understanding of the nature of employment discrimination as a systemic problem affecting numerous individuals throughout the economy. ${ }^{90}$

In a pattern-or-practice case, a plaintiff typically alleges an individual disparate treatment claim and further asserts that the employer's disparate treatment of the plaintiff stems from a general or company-wide "patternor-practice" of intentional discriminatory treatment toward members of the named plaintiff's protected class. ${ }^{91}$ In a pattern-or-practice class action suit, the named plaintiff bears the ultimate burden of establishing by a preponderance of evidence that such pattern or practice is the employer's standard operating procedure. ${ }^{92}$

Pattern-or-practice cases differ fundamentally from other kinds of systemic discrimination such as formal policies of discrimination and facially neutral formal policies with adverse impact on protected groups. A formal policy of discrimination is a facially discriminatory policy regarding employment deeisions such as hiring, termination, and segregation of employees that the employer has explicitly announced. ${ }^{93} \mathrm{~A}$ facially neutral formal policy may be unlawful if it is proven to have a significant adverse impact on a protected group. ${ }^{94}$ Unlike a formal policy of discrimination or

90. E.g., Albemarle Paper Co. v. Moody, 422 U.S. 405, 421 (1975). Albemarle was a class action suit challenging "any policy, practice, custom or usage" by the employer that violated Title VII. Id. at 405. See also Griggs v. Duke Power Co., 401 U.S. 424, 429-30 (1971).

91. See, e.g., Hazelwood, 433 U.S. at 303; Teamsters, 431 U.S. at 335.

92. See Teamsters, 431 U.S. at 336. In a Title VII pattern-or-practice class action suit, the plaintiff bears the initial burden of establishing a prima facie case that such pattern or practice is the employer's standard operating procedure. The prima facie proof of a pattern-or-practice case must consist of evidence other than "isolated or 'accidental' or sporadic" incidents. Id. Statistics plays a pivotal role in establishing such a prima faeie case if a statistically significant disparity can be proven. Hazelwood, 433 U.S. at 307-08 (reeognizing that gross statistical disparities may constitute prima facie proof of a pattern or practice of discrimination); Teamsters, 431 U.S. at 339-40 (stating that statistical analyses will continue to serve an important role in proving employment discrimination). After the plaintiff has established his or her prima facie case, the employer may then rebut the plaintiff's prima facie case. Teamsters, 431 U.S. at 360 . If the employer cannot rebut the prima facie case, the court may then conclude that the employer is liable for a pattern or practice of classwide discrimination. $I d$. at 361. If the employer rebuts the prima facie case by introducing alternative statistical evidence or demonstrating that the plaintiff's statistical calculations are based on flawed methodologies, the plaintiff bears the burden of persuading the trier of fact that the employer's proffered rebuttal is biased. See, e.g., Coates v. Johnson \& Johnson, 756 F.2d 524, 542-45 (7th Cir. 1985).

93. For example, in Los Angeles Department of Water \& Power v. Manhart, an employer required female employees to make larger contributions than male employees to its benefit pension plan because women, as a class, live longer than men. 435 U.S. 702 (1978). The Supreme Court held that the employer's formal policy of discrimination violatcd section 703(a)(1) of Title VIl, which prohibits employers from treating an individual solely on the basis of the individual's common class characteristic such as sex and race. Id. at 704.

94. In Griggs v. Duke Power Co., a plaintiff challenged, on adverse impact grounds, two screening devices used by the employer as a condition for employment and job assignment: an education requirement and a scored test. 401 U.S. at 425 . Griggs held that the employer was prohibited from using the two sereening devices when the devices were not significantly related to job performance but operatcd to disqualify blacks at a substantially higher rate than whites. Id. at 430-32. 
a facially neutral policy with adverse impact on a protected group, a pattern or practice of discrimination is an employer's unannounced standard operating procedure of intentional discrimination.

\section{B. Congressional Intent to Eradicate Pattern-or-Practice Discrimination}

The existence of intractable historically entrenched barriers to the full enjoyment of employment rights preoccupied Congress both before and after the enactment of Title VII. Before the passage of the Civil Rights Act of I964, Congress was fully aware of the economic plight of blacks as a minority racial group. ${ }^{95}$ In the years shortly after the passage of the Act, statistics reported by the Department of Labor showed that the rate of black unemployment had been and continued to be almost double that of white unemployment. ${ }^{96}$ Moreover, Congress exprcssed concerns over the prospect of enhancing the social and economic position of minorities as employers turned to less subtler discriminatory practices. For example, a 1971 Senate Report concluded:

Employment discrimination as viewed today is a ... complex and pervasive phenomenon. Experts familiar with the subject now generally describe the problem in terms of "systems" and "effects"... and the literature on the subject is replete with discussions of, for example, the mechanics of seniority and lines of progression, perpetuation of present effects of pre-act discriminatory practices through various institutional devices . . . ${ }^{97}$

Experience also informed Congress that merely relying on the individual complaint mechanism was inadequate for elevating the social and economic status of minorities and that lawsuits alleging systemic discrimination such as pattern-or-practice suits could challenge industry-wide or company-wide discriminatory practices that private individual actions could not. ${ }^{98}$

Congress clearly considered pattern-or-practice discrimination during the passage of Titlc VII. For example, as Senator Humphrey explained in 1964, a pattern or practice of discrimination exists "if, for example, a number of companies or persons in the same industry or line of busincss discriminated, if a chain of motels or restaurants practiced racial discrimination throughout all or a significant part of its system, or if a

95. In 1963, the median income of blacks was barely sixty percent that of whites. 110 CoNG. REC. 7204 (1964). Compared to $47 \%$ of white workers, only $17 \%$ of nonwhite workers had white collar jobs. Id. at 13091 .

96. See Development in the Law-Employment Discrimination and Title VII of the Civil Rights Act of 1964, 84 HaRV. L. REv. 1109, 1113 (1971) (citing U.S. Bureau of Labor Statistics, MoNTHLY LAB. REV. 69 (Oct. 1970)).

97. S. REP. No. 92-415, at 5 (1971).

98. See, e.g., 110 Cong. Rec. 14270 (I964) (remarks of Sen. Humphrey). 
company repeatedly...engaged in acts prohibited by the statute." 99 Senator Manguson stated that an example of pattern-or-practice discrimination in public accommodation under the proposed Title II of the Civil Rights Act of 1964 "would be a situation in which all or most of the restaurants in a city or town refused to serve persons on account of their race, color, religion, or national origin." ${ }^{100}$ Furthermore, it was clear to Congress that "a pattern or practice would be present only when the denial of rights consists of something more than an isolated, sporadic incident, but is repeated, routine, or of a generalized nature."101

Aware of the troublesome hurdles to achieving equal rights for minority communities, Congress thus intended to eradicate systemic discrimination, and, in particular, pattern-or-practice discrimination, through the enactment of Title VII. More specifically, in section 707(a) of Title VII, Congress granted the EEOC the authority to initiate "pattern-or-practice" suits against employers. ${ }^{102}$ This specific statutory authorization to the EEOC plus the clear evidence that Congress fully understood the nature and pervasiveness of pattern-or-practice discrimination demonstrates that eradication of such type of discrimination was a substantive goal motivating Congress to enact Title VII.

99. 110 Cong. ReC. 14270 (1964). See also 110 Cong. Rec. 14239 (1964) (remarks of Sen. Humphrey) ("It would be clear that an establishment or employer that consistently or avowedly denies rights under [Title II and Title VII] is engaged in a 'pattern or practice of resistance." ").

100. 110 CONG. REC. 12946 (1964) (referring to a section of a proposed bill that came to be section 206(a) of the Civil Rights Act of 1964, 42 U.S.C. $\$ 2000 \mathrm{a}-5$ (2000)).

101. 110 Cong. REC. 14270 (1964) (remarks of Sen. Humphrey); see also 110 Cong. Rec. 13801 (1964) (remarks of Sen. Case) (stating that a pattern or practice of discrimination is "not a single act of discrimination"). Courts have also interpreted the "pattern-or-practice" language in section 707(a) based on the words' generic meaning, not as a term of art. See Teamsters v. United States, 431 U.S. $324,336 \mathrm{n} .16$ (1977) ("The 'pattern-or-practice' language in [section 707(a)] of Title VIl . . was not intended as a term of art, and the words reflect only their usual meaning."); United States v. Mayton, 335 F.2d 153, 158-59 (5th Cir. 1964) ("The words pattern or practice [of violating the Civil Rights Act of 1960] were not intended to be words of art.... Pattern or practice have their generic meanings. In other words, the court finds that the discrimination was not an isolated or accidental or peculiar event; that it was an event that happened in the regular procedures ....") (internal quotation omittcd).

102. Title V11 of the Civil Rights Act of $1964 \S 707$ (a), 42 U.S.C. $\S 2000 \mathrm{e}-6(\mathrm{a})$ (2000). $\S 2000-$ $\mathrm{e}(6)(\mathrm{a})$ provides:

Whenever the Attorney General has reasonable cause to believe that any person or group of persons is engaged in a pattern or practice of resistance to the full enjoyment of any of the rights secured by this title, and that the pattern or practice is of such a nature and is intended to deny the full exereise of the rights herein described, the Attorney General may bring a civil action in the appropriate district eourt of the United States....

The 1972 amendments to Title VII transferred the Attorney General's $\$ 707$ authority to file pattern-orpractice suits against private employers to the EEOC. See 42 U.S.C. $\S 2000 \mathrm{e}-6(\mathrm{c})$ (2000) ("[T]he functions of the Attorney General under this section shall be transferred to the [EEOC] ...."). For an account of the legislative history of the Civil Rights Act of 1972, see Herbert Hill, The Equal Employment Opportunity Acts of 1964 and 1972: A Critical Analysis of the Legislative History and Administration of the Law, 2 1NDUST. REL. L. J. 1 (1977). 


\section{The Pre-Morgan Circuits' Pattern-or-Practice Doctrine}

The lack of uniformity among the pre-Morgan circuits with respect to the application of the continuing violation theory to pattern-or-practice cases arose not only from inter-circuit disagreement over the proper formulation of the procedural theory but also, at times, from intra-circuit failure to provide a coherent formulation. This subpart begins by examining the Ninth Circuit's pre-Morgan jurisprudence before turning to the case law of other circuits, because the Ninth Circuit, which spoke on the issue most frequently, offered a viable formulation of the procedural theory for pattern-or-practice cases.

\section{The Ninth Circuit's Ongoing Policy Standard}

The pre-Morgan Ninth Circuit applied the continuing violation theory to pattern-or-practice cases using an "ongoing policy" standard. Under this standard, a pattern or practice of discrimination is actionable under Title VII if the named plaintiff who seeks to maintain a class action can establish that the pattern or practice has continued into the statute of limitations period. ${ }^{103}$ The ongoing policy standard permits application of the continuing violation theory in a pattern-or-practice class action case, regardless of whether the class plaintiff is able to prove any specific injury caused by the employer during the limitations period. ${ }^{104}$ In other words, under this standard, the class plaintiff's Title VII claim is timely as long as he or she remains subject to the pattern or practice of discrimination.

103. The Ninth Circuit in Morgan stated that a plaintiff who wishes to invoke the continuing violation theory to toll the charge-filing period could prove a "systemic violation" whose operation continued into the charge-filing period. Morgan v. Nat'l R.R. Passenger Corp., 232 F.3d 1008, 1015 (9th Cir. 2000); see also Domingo v. New England Fish Co., 727 F.2d 1429, 1443 (9th Cir. 1984) ("In order for a violation to be continuing, it must involve a practicc, continued over a period of time, which operates to injure the plaintiff individually or as a member of a class to which the plaintiff belongs."); Williams v. Owens-Illinois, Inc., 665 F.2d 918, 924 (9th Cir. 1982) (noting that a systemic policy of discrimination is actionable even if some or all of the events that serve as evidence to its inception occurred prior to the statute of limitations).

104. See Domingo, 727 F.2d at 1443 (citing Reed v. Lockheed Aircraft Corp., 613 F.2d 757, 760 (9th Cir. 1980)). This Casenote adopts an interpretation of the ongoing poliey standard in light of the requirements of Rule 23 of the Federal Rules of Civil Procedure. See General Tel. Co. of the Southwest v. Falcon, 457 U.S. 147, 156 (1982). Rule 23 governs Title VIl elass actions brought by private plaintiffs. Id. at 161. Specifically, the commonality and typicality requirements of Rule 23(a) "serve as guideposts for determining... whether the named plaintiff's claim and the class claims are so interrelated that the interests of the class members will be fairly and adequately protected in their absence." Id. at 157 n.13. Thus, while the class plaintiff need not demonstrate any specific injury, the named plaintiff who brings the action has to prove that he or she has suffered a specific advcrse employment action in order to adequately represent the interests of not only those who were deterred from seeking promotions but also those who actually applied for the positions and were rejected. For a brief discussion of a Title Vll plaintiff's standing to file a class action, see Edward O'Keefe, The Effect of the Continuing Violations Theory on Title VII Back Pay Calculations, 13 Seton HalL L. REv. 262, 282 (1983) ("[W]hile there may well be a continuing violation subject to attack, a plaintiff not adversely affected within the statutory filing period has no standing to attack the violation."). 
On several occasions, the Ninth Circuit clarified when, under the ongoing policy standard, the class plaintiff was indeed subject to the alleged pattern or practice of discrimination during the limitations period. In Reed v. Lockheed Aircraft Corp., the Ninth Circuit declared that a charge of systemic discrimination brought by a present employee is always timely because the discriminatory practice continues to deter the enjoyment of the employee's full employment rights. ${ }^{105}$ Specifically, the Ninth Circuit held that where male employees are unlawfully promoted more regularly than similarly situated female employees, "each day without promotion constitute[s] a new violation of Title VII." Owens-Illinois, Inc., the court warned that because termination places an employee out of reach of an employer's discriminatory policy, a claim by a terminated employee could be time-barred. ${ }^{107}$ So while the pre-Morgan Ninth Circuit case law did not require that the alleged discriminatory pattern or practice cause specific injury within the limitations period, it did insist that the class plaintiff remain exposed to the employer's discriminatory conduct during that period. ${ }^{108}$

The Ninth Circuit's ongoing policy standard provides multiple strategic advantages to Title VII plaintiffs for purposes of eliminating systemic discrimination. Because the standard does not require that specific acts pursuant to a pattern or practice of discrimination occur within the limitations period, it provides flexibility to plaintiffs. In doing so, it removes procedural obstacles to effectuating Title VII's goal of eliminating systemic discrimination.

A pre-Morgan case that illustrates this greater flexibility is Domingo v. New England Fish Corp. ${ }^{109}$ In Domingo, minority employees challenged their employer's recruitment policies. Since the employer recruited by word of mouth for the higher paying jobs, and these jobs were primarily held by whites in a segregated work environment, minority employees were unable to learn of the job openings. ${ }^{110}$ In this situation, requiring plaintiffs to show a specific injury caused by the employers' discriminatory policies within the limitations period would create an enormous hurdle for plaintiffs claiming pattern-or-practice violations. Due to the lack of available information regarding new job openings, these plaintiffs would have failed to apply for them and would thus be unable to allege any specific

105. 613 F.2d 757, 760 (9th Cir. 1980).

106. Id. at $759-60$.

107. 665 F.2d 918, 924 (9th Cir. 1982).

108. See Domingo v. New England Fish Corp., 727 F.2d 1429, 1443 (9th Cir. 1984).

109. 727 F.2d 1429.

110. See id. at 1433-34. 
failure-to-hire or failure-to-promote incidents. They would therefore be barred from recovery based on the employer's systemic discrimination. ${ }^{111}$

Such cases corroborate the notion that the existence of a pattern or practice of discrimination, or any other type of systemic discrimination, by itself ought to be deemed a continuing violation. ${ }^{112}$ Dismissal of the class plaintiffs' pattern-or-practice claim would reward the employer for maintaining a discriminatory policy, even if there has been no incident pursuant to such policy within the charge-filing period.

\section{Other Pre-Morgan Circuits}

While difficult to reconcile, cases from the other pre-Morgan circuits that addressed the application of the continuing violation theory to patternor-practice cases roughly fall into one of three categories: (1) cases that developed an "ongoing-plus theory" standard; (2) cases with conflicting holdings in which the circuit court adopted inconsistent formulations of the procedural theory; and (3) cases that announced inchoate views on the procedural theory. The following discussion provides a survey of the preMorgan circuit court case law and offers examples of each trend.

The pre-Morgan Eighth Circuit developed an "ongoing-plus theory"; standard for cases alleging a pattern or practice of maintaining a hostile work environment. In Jenson v. Eveleth Taconite Co., plaintiffs filed a class action against their employer alleging sex discrimination. ${ }^{113}$ The Eighth Circuit held that a court may deem a pattern or practice of maintaining a hostile work environment ongoing "if the plaintiff [also] establishes that any violation took place during the statutory period." 114 Finding that one of the elass plaintiffs was subjected to sexual harassment on at least one occasion during the charge-filing period, the Jenson court ruled in favor of the plaintiff on her claim for recovery. ${ }^{115}$ In other words, the Eighth

111. The Supreme Court recognized a similar problem in Teamsters $v$. United States when it observed that the consistent enforcement of a diseriminatory hiring policy would more likely than not "deter job applications from those who are aware of it and are unwilling to subject themselves to the humiliation of explicit and certain rejection." 431 U.S. 324, 365 (1977). Thus, the Court specifically held that the minority employee plaintiffs were not required to prove that they had applied for a position in order to establish that they had been injured by the employer's discriminatory hiring policy. See id. at 363-64.

112. See Shehadeh v. Chesapeake and Potomac Tel. Co. of Md., 595 F.2d 711, 724 n.66 (1978) ("A Charging Party may attack a current employment Policy... and, since a policy is by nature continuing, a 'policy' charge always is timely filed ... . Charges which do not specifically include the [word] 'policy,' or otherwise suggest a continuing course of conduct, normally may be read, in context, to allege a continuing, i.e., policy-type, violation.") (citations omitted); see also Charles C. Jackson \& John H. Matheson, The Continuing Violation Theory and the Concept of Jurisdiction in Title VII Suits, 67 GEO. L.J. $811,825 \mathrm{n} .77$ ("[T] on time.") (citation omitted).

113. 130 F.3d 1287, 1303 (8th Cir. 1997).

114. Id.

115. Id. 
Circuit's formulation of the continuing violation theory as applied to pattern-or-practice claims, at least those involving maintenance of a hostile work environment, required that the class plaintiff prove not only the ongoing nature of the discriminatory practice but also the occurrence of a specific incident within the charge-filing period. The "ongoing-plus theory" approach, however, suffered from the inflexibility that the pre-Morgan Ninth Circuit's ongoing theory standard avoided. ${ }^{116}$

The case law of other pre-Morgan circuits indicates that confusion regarding the meaning of the continuing violation theory, with respect to pattern-or-practice cases, arose from the circuits' adoption of contradictory formulations. For example, in Rendon v. AT\&T Technologies, a pattern-orpractice class action brought by a group of African American and Mexican American workers, the Fifth Circuit claimed that a plaintiff may challenge a "discriminatory promotion policy or system" that was "maintained into the charge-filing period," even if the plaintiff was not denied a promotion during the charge-filing period. ${ }^{117}$ However, in Celestine v. Petroleos de Venezuella $S A$, in which more than 200 African Americans alleged a pattern or practice of racial discrimination in promotions and training by the employer, the Fifth Circuit announced-without explicitly overruling Rendon-that a racially motivated failure to promote and train is a "one-time employment event." 18 The Celestine court added that the charge-filing period starts to run on the date that the alleged racially motivated failure-to-promote decision occurs, since the plaintiff "is put on notice" at the time of the occurrence. ${ }^{119}$ In light of pre-Morgan decisions such as Rendon and Celestine, it was therefore impossible to predict whether the Fifth Circuit would allow the continuing violation theory to be applied to pattern-or-practice failure-to-promote or failure-to-train claims and whether the notice requirement as stated in Celestine would always be a factor in determining the timeliness of a pattern-or-practice claim.

Many other pre-Morgan circuit courts failed to develop standards for the application of the continuing violation theory to pattern-or-practice cases. For instance, the Sixth Circuit stated that for claims involving "an established policy of discrimination," the "continuing violation theory applies where a plaintiff challenges not just one incident of unlawful conduct but an unlawful practice that continues into the limitations period." ${ }^{120}$ However, the Sixth Circuit announced its understanding of the

116. See supra notes 109-12 and accompanying text.

117. 883 F.2d 388, 395-96 (5th Cir. 1989).

118. 266 F.3d 343, 352 (5th Cir. 2001) (citing Huckabay v. Moore, 143 F.3d 233, 240 (5th Cir. 1998)).

119. Id.

120. Alexander v. Local 496, Laborers' Int'l Union, 177 F.3d 394, 408-09 (6th Cir. 1999) (citing Hull v. Cuyahoga Valley Joint Vocational Sch. Dist. Bd. of Educ., 926 F.2d 505, 510-11 (6th Cir. 1991)). 
continuing violation theory as applied to systemic discrimination without providing any guidance on how to determine whether an alleged systemic discrimination "continues into" the charge-filing period-that is, whether the class plaintiff is required to allege any special injury caused by the employer's discriminatory practice. Similarly, the pre-Morgan Seventh Circuit discussed three distinct continuing violation standards, none of which directly addresses pattern-or-practice cases. ${ }^{121}$ The pre-Morgan Tenth Circuit acknowledged the applicability of the continuing violation theory to pattern-or-practice cases without providing a developed legal standard. ${ }^{122}$

\section{The Relationship between Continuing Violations and Discrimination in Promotions}

Many pattern-or-practice cases where the plaintiffs allege continuing violations involve denials of promotions or similar types of employment benefits such as job training and transfers. ${ }^{123}$ This can in part be cxplained by the view adopted by many pre-Morgan circuits that denials of promotions are by their nature violations that take place over an extended period of time. One circuit, for example, explained that while failure to hire occurs on a particular day, failure to promote on a prohibited basis "invariably arises during a lengthy period of time." 24 As another circuit stated, "[p]romotion systems, unlike hiring systems, produce [ ] effects that may not manifest themselves as individually discriminatory except in culmination over a period of time." 25

However, termination of employment either through discharge or by resignation brings to an end the employer's discrimination against the plaintiff and therefore activates the charge-filing period for any Title VII violation that has continued up to or occurs on the date of separation. ${ }^{26} \mathrm{In}$

121. See, e.g., Selan v. Kiley, 969 F.2d 560, 565 (7th Cir. 1992) (dividing eontinuing violations into three categories: (1) those involving hiring or promotion practices where the employer's decisionmaking process usually takes place over a period of time; (2) those involving an express formal policy of discrimination; and (3) those involving a series of discriminatory aets).

122. See, e.g., Mascheroni v. Bd. of Regents, 28 F.3d 1554, 1560-61 (10th Cir. 1994) (articulating the standard for applying the continuing violation theory to a series of related discriminatory acts only); Bruno v. W. Elec. Co., 829 F.2d 957, 961 (10th Cir. 1987) (distinguishing between continuing violations such as the oecurrenee of a series of related discriminatory acts from "the maintenance of a discriminatory system" without providing a legal standard for determining how the latter ean be proved to have continued into the charge-filing period).

123. See supra notes $105-22$ and accompanying text.

124. Trevino v. Celanese Corp., 701 F.2d 397, 402 (5th Cir. 1983) (quoting Rich v. Martin Corp., 522 F.2d 333, 348 (10th Cir. 1975) (emphasis removed from original)). But see Celestine v. Petroleos de Venezuella SA, 266 F.3d 343, 352 (5th Cir. 2001) (stating that failure to promote is a "one-time employment event").

125. Rendon v. AT\&T Techs., 883 F.2d 388, 396 (5th Cir. 1989) (internal quotation omitted).

126. See Laffey v. Northwest Airlines, 567 F.2d 429, 473 (D.C. Cir. 1977); Olson v. Rembrandt Painting Co., 511 F.2d 1228, 1234 (8th Cir. 1975) (claiming that termination of employment either through discharge or by resignation "puts at rest the employment discrimination"). $C f$. Reed v. 
light of the legal standards examined in this Part and against the backdrop of clear Congressional intent to eradicate pattern-or-practice discrimination, Part III first analyzes the doctrinal distinction between discrete acts and repeated conduct as promulgated in Morgan and then explores the plausible implieations that Morgan has on future pattern-or-practice elaims, the majority of which involve denials of promotions.

\section{III}

\section{Pattern-or-Practice Cases in the Post-Morgan Era}

As indicated by the divergent interpretations adopted by, or the lack of a developed standard within, the pre-Morgan circuits, a unified approach to the application of the continuing violation theory to pattern-or-practice cases is long overdue. ${ }^{127}$ Because Morgan explicitly stated that its holding did not address the issue of how the continuing violation theory should apply to pattern-or-practice cases, ${ }^{128}$ eourts will either follow their preMorgan precedent regarding the procedural theory as applied to pattern-orpractice cases or, more plausibly, grapple with the issue by analogizing from Morgan's reasoning. With respect to the latter possibility, it is important to note that in its interpretation of the continuing violation theory for non-pattern-or-practice cases, the Morgan majority relied on precedent such as Bazemore v. Friday, a pattern-or-practice case. ${ }^{129}$ Such an analytical misstep by the Court will likely generate uncertainty in post-Morgan lower courts over the precise relationship between Morgan and pattern-orpractice claims.

Part III first argues that the doctrinal distinction between discrete and nondiscrete acts as adopted by the Morgan majority is the product of a judicial compromise between attending to employers' interests on the one hand and preserving some employees' rights on the other. As a consequence, the distinction fails to reflect adequately the empirical nature of employment discrimination such as discriminatory decision-making processes regarding promotions, which usually take place over an extended period of time. This Part proposes that lower courts adopt a case-by-case analysis to assess the "discreteness" of an alleged employment practice, or the lack of it, before applying the Morgan majority's rule that the continuing violation theory is inapplicable to discrete acts.

Lockheed Aircraft Corp., 613 F.2d 757, 761 (9th Cir. 1980) ("A challenge to systemic discrimination is always timely if brought by a present cmployee, for the existencc of the system deters the employce from seeking his full employment rights or threatens to adversely affect him in the future.") (quoting Elliot v. Sperry Rand Corp., 79 F.R.D. 580, 586 (D. Minn. 1978)).

127. See supra notes 103-22.

128. 536 U.S. 101, 115 n.9 (2002).

129. Id. at 111-12 (citing Bazemore v. Friday, 478 U.S. 385 (1986), as an example in which the Supreme Court interpreted the term "practice" to apply to a discrete act). See also supra note 11. 
This Part then proceeds to examine the implications of Morgan on the application of the continuing violation theory to pattern-or-practice cases. Specifically, this Part discusses a recent Ninth Circuit decision, Lyons $v$. England, which applied the Morgan majority's doctrinal distinction. ${ }^{130}$ Lyons suggests that construction of the continuing violation theory for pattern-or-practice cases within the Morgan majority's doctrinal distinction would be detrimental to the interests of class action plaintiffs, as well as to Title VII's goal of eliminating systemic discrimination. This Part then addresses concerns over the implications of Morgan on pattern-or-practice cases concerning wage discrimination and on back pay award calculations in the remedial phase of a pattern-or-practice suit. This Part concludes that lower courts should refrain from applying Morgan to pattern-or-practice cases and instead should construe the continuing violation theory broadly in order to further the substantive goals of Title VII.

\section{A. Morgan's Doctrinal Distinction between Discrete Acts and Repeated Conduct}

The fallacy of the Morgan majority's reasoning, as explained below, betrays the fact that the majority's differentiation between discrete discriminatory and retaliatory acts on the one hand and hostile work environments of a repeated nature on the other arose not from a determination of some inherent distinction between these two kinds of conduct, but rather from a judicial compromise between conflicting interests. In fact, the Morgan majority's adoption of an all-or-nothing doctrinal distinction between discrete and nondiscrete acts perpetrates an analytical move away from perceiving unlawful employment practices as a range of discriminatory practices of varying kind and degree. The latter view, which the preMorgan Ninth Circuit's "sufficient relation" standard endorsed and many pre-Morgan circuits adopted with respect to employment practices such as promotions, better mirrors the empirical nature of employment discrimination than the majority's doctrinal distinction does.

\section{Morgan as a Judicial Compromise}

According to the Morgan majority, conduct in violation of Title VII can readily be categorized as one of two things: a discrete act or part of a repeated course of conduct. ${ }^{131}$ In applying the continuing violation theory in Morgan, the Court carved out an exception to the discrete act rule in hostile work environment cases. However, its analytical reason for doing so was contradictory and inconsistent.

Seeking support for the interpretation that the term "unlawful employment practice" in Title VII signifies discrete acts, the Morgan 
majority referred to the plain language of the relevant provision of Title VII. ${ }^{132}$ Specifically, it observed that Title VII provides:

It shall be an unlawful employment practice for an employer-

(1) to fail or refuse to hire or to discharge any individual, or otherwise to discriminate against any individual with respect to his compensation, terms, conditions, or privileges of employment, because of such individual's race, color, religion, sex, or national origin .... ${ }^{133}$

From the plain language of the statute, the majority then concluded that there is no indication that a series of related discrete acts should be subsumed under the term "practice," and thus rejected the Ninth Circuit's "sufficient relation" standard. ${ }^{134}$

However, Title VII also proscribes discriminatory employment practices that are usually not considered to be discrete acts. More specifically, the statute states that it is an "unlawful employment practice" for an employer "to limit, segrcgate, or classify his employees or applicants" in any way that would adversely affect their employee status or deprive them of job opportunities. ${ }^{135}$ Segregation or classification of employees based on their race, color, religion, sex, or national origin in a workplace with many employees, for example, does not take place on one single day in one single discrete act, but rather requires days and multiple undertakings in order to be fully implemented. Thus, even if the Morgan majority is correct in resorting to the plain meaning of the statute for justification of its rule for discrete acts, its reading of the statute is incomplete and therefore leads to the formulation of a rule that the statutory language does not fully support.

Furthermore, in characterizing the repeated nature of hostile work environments, the Morgan majority, instead of adhering to the "plain language" approach to interpreting Title VII as it did for discrete acts, relied upon a well-respected treatise on employment discrimination law. ${ }^{136}$ Additionally, in cxplaining why workplace harassment, which may not result in economic or tangible injury in the way that discrete discriminatory acts often do, is actionable, the majority attended to the legislative intent of "strik[ing] at the entire spectrum of disparate treatment." 137 By resorting to secondary resources and legislative intent, it thereby went beyond the ordinary meaning of the statutory phrase "terms, conditions, or privileges of

132. 536 U.S. at $109-11$.

133. Id. at 111 (quoting Title VIl of the Civil Rights Act of $1964 \S 703(\mathrm{a}), 42$ U.S.C. $\S 2000 \mathrm{e}-2$ (a) (2000)).

134. Id.

135. 42 U.S.C. $\S 2000 \mathrm{e}-2(\mathrm{a})(2)(2000)$.

136. 536 U.S. at 115 (citing 1 LindemanN \& Grossman, supra note 4 , at $348-49$ for the proposition that the repeated nature of workplace harassment serves as evidence of an employer's knowledge of its existence).

137. 536 U.S. 101, 116 (citations omitted). 
employment." ${ }^{138}$ However, if the congressional intent of eliminating the entire spectrum of discriminatory employment practices, which includes not only hostile work environments but also series of individual discriminatory acts, serves as a legitimate justification for permitting acts outside the charge-filing period in a hostile work environment claim to be actionable, it is hard to see why the majority could not apply the same justification to "discrete acts" that are sufficiently related, as under the pre-Morgan Ninth Circuit's standard. ${ }^{139}$ In other words, while the Morgan Court's justifications for considering an act to be "repeated conduct" and thus actionable in the context of a hostile work environment could easily support the same analysis for disparate treatment claims, the Court, on unpersuasive grounds, chose not to take this approach. This methodological inconsistency raises the question as to what in fact motivated the majority's doctrinal distinction between discrete and repeated acts. ${ }^{140}$

In light of the dubious doctrinal distinction of the Morgan majority's holding and the majority's methodological inconsistency, it appears that the majority sought to strike a balance between employer defendants' concerns over liability and employee plaintiffs' interests in redress. By categorically barring claims based on the so-called "discrete" acts of discrimination and retaliation that fall outside the charge-filing period, the Supreme Court relieved employers of the burden of ever having to worry about defending stale claims ${ }^{14 !}$ or being liable for claims involving years of illegal conduct.

By categorically permitting the entire period of an alleged hostile work environment to be considered timely as long as an incident contributing to it falls within the charge-filing period, the Morgan majority thus guaranteed victims of hostile work environments the opportunity of waiting to amass sufficient evidence to establish their claims, since one essential element of a successful hostile work environment claim is proving pervasiveness or severity of the conduct creating it. ${ }^{142}$ The dissent's approach would have barred the application of the continuing violation theory to hostile work environment claims and thus would have created a

138. Id. at 116.

139. See supra notes $18-21$ and accompanying text.

140. The only apparent methodological consistency in the Morgan majority's opinion is the fact that it cited Supreme Court precedent in support of its holding with respect to both discrete discriminatory and retaliatory acts and hostile work environments.

141. It is unclear how much bite this concern over defending stale claims has regarding pattern-orpractice cases. If the maintenance of a pattern or practice of discrimination has indeed continued from outside the charge-filing period into the charge-filing period, employers would then always be on notice of potential claims against them. See Havens Realty Corp. v. Coleman, 455 U.S. 363, 380 (I982) ("Statutes of limitations... are intended to keep stale claims out of the courts .... Where the challenged violation is a continuing one, the staleness concern disappears.") (citations omitted).

142. See, e.g., Harris v. Forklift Systems, Inc., 510 U.S. 17, 23 (1993) ("[W] hether an environment is 'hostile' or 'abusive' can be determined only by looking at all the circumstances. These may include the frequency of the discriminatory conduct; its severity ...."). 
more unified approach to reviewing claims of continuing violations. Given the logical appeal of the dissent's argument, the majority's refusal to follow the dissent further supports the view that the majority was driven by its desire to address employers' concerns and at the same time preserve some rights for victims of employment discrimination.

\section{The (Un)tenability of Morgan's Doctrinal Distinction}

\section{a. Morgan's Mischaracterization of Discriminatory Promotion Practices}

In its attempt to reach a workable compromise between conflicting interests, the Morgan majority's holding probably raised more questions than it answered. First of all, whether a discriminatory act is discrete or nondiscrete, or whether it can be subsumed under either one of these two categories, often cannot be determined without taking into account the context in which it occurs. For example, a denial of promotion, which the Morgan majority considered to be a discrete act but many pre-Morgan circuits considered to be a continuing violation, may involve multiple levels of decision making. ${ }^{143}$ Such a decision-making process may span a period of weeks or even months, and discriminatory acts may take place at various stages involving multiple decision makers. The Morgan majority's holding that acts such as failures to promote are discrete acts and therefore can never be a continuing violation contradicts many pre-Morgan circuits' correct understanding of the empirical nature of promotion practices. ${ }^{144}$

One scenario that helps illustrate the problem of characterizing promotion decisions as discrete acts is that in which the decision to promote an employee requires recommendations from three supervisors, the employer makes no offer unless all three supervisors recommend the employee, and the employee knows of such a requirement. Suppose that the employee learns of her supervisors' refusals to recommend her at different points in time and that all of these decisions are motivated by a statutorily prohibited basis such as her sex. Should the sum of all these three "discrete" decisions be considered as one discrete act? For the purpose of filing a timely charge, should the statute of limitations start to run on the final communication from the employer that this employee is not offered the promotion? On the other hand, since she would be denied the promotion as long as any one of the three supervisors declines to recommend her, should the limitations period start to run on the first decision by

143. See supra notes $124-25$ and accompanying text.

144. See, e.g., Rebecca Hanner Whitc \& Linda Hamilton Krieger, Whose Motive Matters?: Discrimination in Multi-Actor Employment Decision Making, 61 LA. L. Rev. 495, 496 (2001) (stating that at times employment decisions involve multiple decision makers, thus making it difficult to determine whose intent matters in a potential case of disparate treatment, which requires the plaintiff to prove a discriminatory intent). 
her supervisor, even though she has not been "officially" notified that she is not offered a promotion? These are important charge-filing and thus liability-related questions that the Morgan majority never addressed in its delineation of the doctrinal distinction between discrete acts and repeated conduct.

The notice requirement, as proposed in Justice O'Connor's concurrence in Morgan, would not resolve these issues. This requirement would permit a plaintiff to state a claim based on discrimination from before the charge-filing period if he or she had not or should not have had notice of the acts. However, such a requirement would only address the issue of when the discriminatory practice "occurs" for the purpose of timely charge filing. ${ }^{145}$ Nonetheless, it still leaves open the question of what constitutes a discriminatory practice such as a denial of promotion - that is, the question of what discriminatory practice the plaintiff"s notice should be "of."

In Delaware State College v. Ricks, which involved a denial of tenure claim by a professor, the Supreme Court held that the statute of limitations started to run on the date the tenure decision was made and communicated to the plaintiff. ${ }^{146}$ However, in the failure-to-promote hypothetical presented above, it is at least unclear whether the statute of limitations starts to run on the date the employee knows of the discriminatory act of one of the supervisors or on the date the employer officially notifies her of its decision not to promote her. A notice requirement that imposes a duty to file an EEOC charge once the plaintiff possesses knowledge of sufficient facts indicating some sort of discrimination would then obligate the employee in the hypothetical to file a charge immediately upon her knowledge of the supervisor's decision. ${ }^{147}$ Such a requirement, however, would deprive a victim of employment discrimination of the option of trying to resolve the issue with the employer informally or through the employer's internal grievance procedure first. On the other hand, a notice requirement that imposes a duty to file a charge only when the employer officially informs the plaintiff of its decision would still suffer the problem of the notice requirement suggested by Justice O'Connor in Morgan. That is, it would still fail to address the nondiscrete nature of discriminatory promotion practices.

The position taken by many pre-Morgan circuits that failure to promote based on a prohibited basis is by nature a continuing violation offers

145. Justicc O'Connor did not explain what criteria to use to dctcrmine when an employee "should have" found out about the adverse employment action. See supra note 83 and accompanying text. It is difficult to formulate a "reasonable employee" standard that is suitable to a case-by-case analysis involving the specific factual situation of the plaintiff employee.

146. 449 U.S. 250,258 (1980).

147. See, e.g., Wcbb v. Ind. Nat'l Bank, 931 F.2d 434, 436, 437 (7th Cir. 1991) (deeming the charge-filing period to begin running on the date the plaintiff knows of the cmployer's discriminatory conduct, not on the date the plaintiff is denied promotion). 
the best starting point for courts to analyze the continuing nature of promotion practices. Instead of categorically following the Morgan majority's rule that promotions are always readily identifiable and discrete, courts should consider failure-to-promote claims on a case-by-case basis to examine whether the alleged denial of promotion is indeed readily identifiable and discrete before deciding whether to apply Morgan's rule for discrete acts and therefore whether the continuing violation should apply. ${ }^{148}$ Alternatively, the language of the Morgan opinion may be read to suggest that the determination of whether an employment practice is a discrete act is partly contingent upon how easy to identify it is. ${ }^{149}$ This reading leaves room for courts to make their own determinations as to whether an act is indeed easy to identify and therefore discrete.

\section{b. Morgan's Doctrinal Incoherence}

Aside from the difficulty of the Morgan majority's rule for discrete acts in adequately accommodating failure-to-promote claims, a careful reading of the Morgan majority's analysis of the plaintiff's Title VII claims reveals a breakdown of the analytical distinction between the types of conduct that constitute discrete acts on the one hand, and the types of conduct that contribute to the existence of a hostile work environment on the other. The pre-limitations acts that Morgan alleged included incidents in which he was "wrongfully suspended and charged with a violation of Amtrak's Rule ' $L$ ' for insubordination while failing to complete work assigned to him, denied training, and falsely accused of threatening a manager."'150

With respect to Morgan's hostile work environment claim, the majority cited approvingly the Ninth Circuit's holding, which took into account both the pre-limitations and post-limitations incidents. Those incidents that the Ninth Circuit considered included not only "the use of racially derogatory language, and the overall racially-laden environment" 151 but also Amtrak's "decision to hire Morgan at a lower grade than others, Morgan's multiple disciplines, and the denial of training." ${ }^{.152}$ Given that the

148. Unfortunately, many post-Morgan courts have already adopted Morgan's categorical rule for discrete acts without conducting a more searching ease-by-case analysis. See, e.g., Foster v. Overnite Transp. Co., No. 01-2854V, 2003 WL 297544 (W.D. Tenn. 2003) (order granting summary judgment) (holding, on the basis of the plain language of the Supreme Court's Morgan decision, that the failureto-promote act alleged by thc plaintiff was a diserete act, which commenced the statute of limitations period); Kaster v. Safcco Ins. Co. of Am., 212 F. Supp. 2d 1264, 1269 (D. Kan. 2002) (citing another court's finding the Supreme Court's dccision in Morgan was "fatal" to a plaintiff's continuing violation theory asserted in the failure-to-promote context and categorically denying relief for all denials of promotions that took place prior to the plaintiff's charge-filing period) (quoting Jarmon v. Powell, 208 F. Supp. 2d 21, 28-30 (D.D.C. 2002)).

149. See Nat'l R.R. Passenger Corp. v. Morgan, 536 U.S. 101, 114 (2002) ("Discrete acts such as termination, failurc to promote, denial of transfer, or refusal to hire are easy to identify.").

150. Id.

151. Morgan v. Nat'l R.R. Passenger Corp., 232 F.3d 1008, 1015, 1017 (9th Cir. 2000).

152. Id. 
majority considered "termination, failure to promote, denial of transfer, or refusal to hire" to be discrete acts because they are "easy to identify,"153 it reasonably follows that Amtrak's decision to offer Morgan a lower level position, unwarranted disciplinary actions, and denial of training opportunities should also be "easy to identify."

If these "discrete" acts could contribute to the existence of a continuing violation, namely a hostile work environment, it is puzzling why they cannot be considered as a series of discriminatory and retaliatory acts by themsclves comprising a continuing violation and thus deemed timely. Put differently, the discrete acts that constitute discriminatory or retaliatory act claims and the repeated conduct that characterizes hostile work environments often overlap, as in Morgan's allegations, in that many of the allegations a plaintiff makes in his or her discriminatory or retaliatory act claims may also contribute to the existence of a hostile work environment. If these "discrete" discriminatory or retaliatory acts contribute to a hostile work environment, to which the Morgan majority held the continuing violation theory applies, then it is unclear why the same acts themselves cannot constitute a continuing violation.

Proponents of the Morgan majority's decision who wish to limit the scope of the continuing violation theory might respond that liability for discrete acts, unlike a hostile work environment, does not depend upon proof of repeated conduct extending over a period of time. This would simply beg the question of why discrete acts as understood by the Morgan majority may not constitute a continuing violation. ${ }^{154}$ The purpose of asking whether the continuing violation theory should apply to a series of discrete acts is to determine the scope of an employer's potential liability. Claiming that employers may be liable for the entire period of a hostile work environment but not pre-limitations discrete acts does not address the problematic doctrinal distinction between discrete acts and repeated conduct as discussed herein. Morgan's invocation of discrete acts as evidence for both discrimination and retaliation claims and hostile work environment claims thus seriously calls into question the tenability of its doctrinal distinction.

Another possible response, this time by advocates for employees, is that despite the rigid rules promulgated by the Morgan majority, victims of employment discrimination can always cast their claims as hostile work environment claims. Morgan was able to successfully make allegations that

153. Morgan, 536 U.S. at 114.

154. In a slightly different context, the Morgan majority applicd a similar argument. In support of its holding regarding hostile work environment claims, the Morgan majority argued that whether this type of claim is actionable should not depend on whether the violation occurs in a defcrral state where the limitations period is 300 days, or in a nondeferral state where the limitations period is 180 days. Id. at 119-20. However, it claimed that this argument did not apply to discrete acts since liability for them did not turn on repeated conduct. $I d$. at $120 \mathrm{n} .12$. 
contributed both to his discrimination and retaliation claims and also to his hostile work environment claims because he suffered not only tangible employment actions such as suspensions and terminations but also subjection to racial epithets and racially derogatory acts, which are incidents constitutive of a hostile work environment. ${ }^{155}$ The strategy of couching one's claim in hostile work environment terms, however, may not be a viable course of action for a plaintiff with a claim alleging multiple failures to promote but not other incidents typical of a hostile work environment. It is difficult to imagine that a court following the Morgan majority's doctrinal distinction would also hold that an alleged series of denials of promotions, each of which is a discretc act, constituted a repeated course of conduct as in a hostile work environment and should therefore be considered a continuing violation.

Morgan's problematic doctrinal distinction clearly stems from the majority's compromise at the expense of accurately capturing the empirical nature of employment discrimination. First of all, the all-or-nothing doctrinal distinction between discrete and nondiscrete acts fails to provide an adequatc conccptual framework to analyze allegations such as failure-topromote claims involving multiple decision makers and decision-making levels occurring over a period of time. Furthermore, the observation that, despite the doctrinal distinction it espoused, the Morgan majority permitted discrete acts to be constituents of a hostile work environment presents much difficulty in its promulgation of the doctrinal distinction between discrete acts and repeated conduct as the principle that delineates the scope and application of the continuing violation theory.

Without abandoning the doctrinal distinction adopted by the Morgan majority, courts confronted with claims involving what the Morgan Court called discrete acts should examine the discreteness of the alleged acts on a case-by-case basis. When lower courts find that the alleged acts exhibit characteristics akin to those of promotion practices, courts should then apply the Ninth Circuit's "sufficient relation" standard, which looks into the relationships among, and the plausible similarities of, the alleged incidents. ${ }^{156}$ The sufficient relation standard is appropriate for determining the existence of continuing violations of such a type because it comes much closer to mirroring the rcal life, fact-specific spectrum of disparate

155. See supra note 26 and accompanying text.

156. See supra notes 18-22 and accompanying text. The pre-Morgan Ninth Circuit's "sufficient relation" standard is preferable to the pre-Morgan Fifth Circuit's Berry test for determining the applicability of the continuing violation theory to a series of acts. The Berry test's degree-ofpermanence factor favored the construction that the statute of limitations under Title VII starts to run as soon as the employee plaintiff becomes aware of the violation of his or her Title VII rights. See Berry v. Bd. of Supervisors of L.S.U., 715 F.2d 971, 98 I (5th Cir. 1983). Thus, the Berry test, by adhering to a strict notice requirement, suffered shortcomings similar to those of the notice requirement that Justice O'Connor proposed in Morgan. See Morgan, 536 U.S. at 123-24. 
treatment of varying kind and degree than the Morgan majority's doctrinal distinction does.

The approach outlined here would solve the problems encountered in the failure-to-promote hypothetical, in which the recommendations of the three supervisors are required for the employee's promotion. In that hypothetical, the sufficient relation standard would find the decisions of the three supervisors and the official announccment of the denial of promotion to be sufficiently related and therefore a continuing violation, as long as one of these incidents takes place within the charge-filing period. Courts should consider acts outside the charging-filing period to be untimely only when there is clear evidence that they are "discrete" in the Morgan majority's terms-that is, "easy to identity."

\section{B. The Application of Morgan to Pattern-or-Practice Cases?}

Although the Morgan majority made clear that it had no occasion to consider the application of the continuing violation theory to pattern-orpractice cases, it also never explicitly prohibited lower courts from adopting its doctrinal distinction between discrete and nondiscrete acts in such cases. While courts could follow their pre-Morgan precedent regarding pattern-or-practice cases, it is likely that, in the absence of any clear guidance from the Supreme Court on the issue and given the lack of developed or consistent formulations of the procedural theory among most preMorgan circuits, ${ }^{157}$ lower courts will try to analyze pattern-or-practice cases within the conceptual framework as informed by the Morgan doctrinal distinction. The pre-Morgan courts, however, understood pattern-orpractice discrimination as an employer's standard operating procedure, not in terms of the rigid, incoherent distinction the Morgan Court drew between discrete and nondiscrete acts. ${ }^{158}$ Applying an analytic framework based on such a distinction will result in undesirable consequences to plaintiffs. Disparate treatment plaintiffs will lose the strategic benefits of pursuing pattern-or-practice cases, which will therefore make it harder to fulfill Title VII's goal of eliminating systemic discrimination.

In fact, one post-Morgan Ninth Circuit decision suggests that courts may move in precisely that direction. In Lyons $v$. England, while the Ninth Circuit recognized that the Morgan majority did not rule on the Ninth Circuit's pre-Morgan application of the continuing violation theory to pattern-or-practice cases, it noted that the Supreme Court did not specifically endorse its pre-Morgan construction either. ${ }^{159}$ In Lyons, the plaintiffs, who were African American male veterans, alleged that their employer engaged in a pattern or practice of discrimination against African American males

157. See supra notes 113-24 and accompanying text.

158. See, e.g., Int'I Bhd. of Teamsters v. United States, 431 U.S. 324, 336 (1977).

159. 307 F.3d 1092, 1106 (9th Cir. 2002). 
by denying them favorable work assignments and job promotions over a period of several consecutive years. ${ }^{160}$ Because the district court interpreted the plaintiffs' claims as separate causes of action instead of a classwide pattern-or-practice case and ruled on each one individually, the Ninth Circuit reviewed the plaintiffs' claims as ones based on discrete discriminatory acts. ${ }^{161}$ The Ninth Circuit thus held that, under Morgan, the claims were timely only if the discrete acts they were based on occurred within the charge-filing period. ${ }^{162}$

Although the Ninth Circuit clarified that plaintiffs after Morgan are not precluded from filing classwide pattern-or-practice claims, ${ }^{163}$ its postMorgan characterization of systemic discrimination in Lyons is sharply different from its pre-Morgan understanding. The Ninth Circuit in Lyons asserted that "[a] discriminatory practice, though it may extend over time and involve a series of related acts, remains divisible into a set of discrete acts, legal action on the basis of each of which must be brought within the statutory limitations period." 164 Specifically, the Ninth Circuit asserted that plaintiffs after Morgan are not precluded from a "pattern-or-practice claim based on a series of discrete acts, including, for example, separate incidents of an employer's failure-to-train and failure-to-promote." 165 Thus, there is a clear indication that the Ninth Circuit would likely now analyze a plaintiff's pattern-or-practice claim under Morgan's problematic doctrinal distinction between discrete and nondiscrete acts.

The construction of a pattern-or-practice case as a series of discrete acts could have at least two potentially devastating effects on the ability of pattern-or-practice class action plaintiffs to seek relief. First, the preMorgan Ninth Circuit's construction of the continuing violation theory allows the entire period of the existence of the alleged systemic discrimination to be actionable as long as it has continued into the charge-filing period. ${ }^{166}$ In contrast, if the post-Morgan Ninth Circuit construes a pattern or practice of discrimination as a series of separate, discrete incidents, as opposed to a series of related incidents in a hostile work environment, it would categorically exempt an employer from any liability for systemic discrimination prior to the charge-filing period. The direct outcome of this exemption is that plaintiffs will be unable to obtain relief for any prelimitations violations if employers are only liable for a violation during the 180 - or 300-day charge-filing period.

160. Id. at $1100-01$.

161. Id. at $1107 \mathrm{n} .8$.

162. Id.

163. Id. at 1108 .

164. Id. at 1107 n.8.

165. Id.

166. See supra notes 103-04 and accompanying text. 
Second, the pre-Morgan Ninth Circuit's construction does not require that the class plaintiff suffer a specific injury pursuant to a pattern or practice of discrimination during the charge-filing period but only that the plaintiff continue to be subject to the systemic discrimination. ${ }^{167}$ The post-Morgan construction, that a pattern-or-practice claim is essentially based on a series of discrete incidents, would likely lead courts to conclude that some specific injury to the plaintiff would have to take place within the charge-filing period. More specifically, would a named plaintiff in a classwide pattern-or-practice claim havc to establish that each member of the class suffered a spccific injury within the charge-filing period, or would it suffice for only some or one of the class members to have suffered a specific injury during that period? The construction that a pattern-or-practice of discrimination claim, like a hostile work environment claim, involves repeated conduct ${ }^{168}$ would not avoid this issue. The Morgan majority specifically held that for the continuing violation theory to be applicable, at least one of the incidents contributing to an alleged hostile work environment must occur within the charge-filing period. ${ }^{169}$

A restriction that plaintiffs of pattern-or-practice cases must suffer some specific injury occurring within the charge-filing period would not only deny plaintiffs adequate relief; it would also withhold the strategic benefits of the ongoing policy standard as promised by the pre-Morgan Ninth Circuit. As discussed in Part Il of this Casenote, a company-wide pattern or practice of discrimination would likely deter job applications from members of the injured protected class. The requirement that plaintiffs suffer some specific injury occurring within the statute of limitations pcriod would discourage victims of systemic discrimination from pursuing Title VII actions and thus generate obstacles to Title VII's goal of eliminating systemic discrimination.

Morgan will also likely reach pattern-or-practice claims concerning wage discrimination. Citing Bazemore v. Friday's much quoted proposition that "[e]ach week's paycheck that delivers less to a black than to a similarly situated white is a wrong actionable under Title VII," 170 the Morgan majority sought support for its claim that the Supreme Court had consistently applied the term "practice" to discrete acts. ${ }^{171}$ Although the Morgan majority claimed that Morgan was silent on pattern-or-practice

167. See supra notes 103-12 and accompanying text.

168. See, e.g., Campbell v. Nat'l R.R. Passenger Corp., 222 F. Supp. 2d 8, 11 (D.D.C. 2002) ("Pattem and practice claims, like hostile work environment claims, involve 'repeated conduct' and a 'series of separate acts' comprising a single 'unlawful employment practice."') (quoting Nat'l R.R. Passenger Corp. v. Morgan, 536 U.S. 101, 115-16 (2002)).

169. 536 U.S. at 116.

170. Bazemore v. Friday, 478 U.S. 385,395 (1986) (involving a racially discriminatory salary system that continued into the charge-filing period).

171. 536 U.S. at 111-12. 
cases, it cited Bazemore, a pattern-or-practice case, for justification of its position on discrete acts. This troubling fact will likely generate revision of lower courts' prior interpretation of Bazemore within the Morgan doctrinal distinction between discrete acts and repeated conduct. It is plausible that lower courts would collapse pattern-or-practice cases into claims about series of discrete discriminatory acts.

In fact, in Inglis $v$. Buena Vista University, ${ }^{172}$ a district court in the Eighth Circuit provided an account of Morgan's possible implications on pattern-or-practice cases conccrning wage discrimination. Specifically, in light of Morgan, the district court said, "[t]he Bazemore holding supports the conclusion that receipt of allegedly discriminatory pay is a discrete act of discrimination that does not warrant application of the continuing violation theory."173 Furthermore, "Morgan will likely halt the previous trend of analyzing pay claims under a continuing violations theory without distinguishing between discriminatory pay policies and discrete discriminatory acts." 174 If Inglis's reading of Morgan becomes the dominant post-Morgan understanding of pattern-or-practice suits concerning wage discrimination, many plaintiffs of such suits will be unable to invoke the continuing violation theory, which could subject employers to liability dating back as far as the beginning of plaintiffs' employment with them.

Finally, lower courts' adoption of Morgan's proposition that employment practices, such as failure to promote, are discrete acts may result in tremendous reduction of the back pay awards to class plaintiffs during the remedial phase of pattern-or-practice suits. A hypothetical may help illustrate this point. Suppose that a telemarketing company hired one hundred sales associates at the beginning of each year starting in I990 and that, in the Class of 1990, fifty were men, and the other fifty women. One of the fifty female sales associates was Pam. At the beginning of their employment each year, the employer provided training to each sales associate in the new class, both to ensure excellent customer service and aggressive sales strategies and also to prepare the associates for possible advancement within the company. Among the Class of I990, fifty received promotions and thus pay increases by the end of the year. Ninety-eight percent of those promoted were males. At the end of each of the following years, the percentage of men and the percentage of women in the respective class who received promotions were roughly the same as in the Class of 1990.

In mid-2002, the company underwent a change in its leadership and consequently in its hiring policy, so $50 \%$ of the Class of 2002 who

172. 235 F. Supp. 2 d 1009 (N.D. Iowa 2002).

173. Id. at I023; see also Peters v. City of Stamford, No. 3-99-CV-764, 2003 WL 1343265, at *5 (D. Conn. March 17, 2003) (order granting partial summary judgment) ("Like termination, failure to promote, or refusal to hire, the issuance of a discriminatory paycheck is 'easily identifiable' and 'can be pinpointed in time."') (quoting Inglis, 235 F. Supp. 2d at I023).

174. Inglis, $235 \mathrm{~F}$. Supp. $2 \mathrm{~d}$ at 1024. 
received promotions were women. At the beginning of October 2002, Pam, who was still an employee of the company and despite her qualifications and persistent efforts had never received a promotion, filed an EEOC charge against the company, alleging that the company had engaged in a classwide pattern or practice of denying female entry-level sales associates promotions because of their sex. The district court found liability against the company. Now, in the remedial phase of the litigation, for the purpose of determining back pay awards for each class member, the district court attempts to calculate the wage discrepancy between how much the class plaintiff has made and how much she would have made absent discrimination, within the two-year back pay period.

Title VII allows for recovery of back pay for up to two years prior to the charge-filing date. ${ }^{175}$ The key question then becomes: in the case of Pam or any similarly situated class plaintiff, should her comparator be the similarly situated male employee from the Class of 2000 who was promoted at the end of 2000 or the similarly situated male employee from the Class of 1990 who now holds an upper management position in the company with an annual salary ten times higher than that of his counterpart who joined the company ten years later? If failure to promote is considered a continuing violation, then her comparator should be the latter-that is, the back pay award should be the difference between how much the similarly situated male sales associate from the Class of 1990 has made in the two-year back pay period and how much Pam has made in that same period. If promotion is considered a discrete act, then courts will likely hold that it is the former-that is, the back pay award should be the difference between how much the similarly situated male from the Class of 2000 has made during the back pay period and how much Pam has made during that same period. The difference between the two awards can be significant.

Applying Morgan's doctrinal distinction to pattern-or-practice cases, both during the liability and the remedial phase, it becomes clear that the doctrinal distinction is problematic in various respects. First of all, the doctrinal distinction, a product of judicial compromise that poorly reflects the empirical complexities of employment discrimination, fails to provide an adequate framework for individual disparate treatment claims based on incidents that cannot be easily subsumed under either "discrete acts" or "repeated conduct." More problematically, construing the continuing violation theory for pattern-or-practice claims within Morgan's rigid, incoherent doctrinal distinction would likely lead to consequences detrimental to the interests of class action plaintiffs. As discussed in Part II, Congress specifically endorsed the use of class actions to end systemic discrimination. Morgan's doctrinal distinction fails to honor the purposes behind Title

175. See 42 U.S.C. $\$ 2000 \mathrm{e}-5(\mathrm{~g})(1)(2000)$. 
VII: the eradication of historically entrenched and systemic barriers to full enjoyment of Title VII rights ${ }^{176}$ and the provision of make-whole relief to those who suffer injuries on account of unlawful employment practices. ${ }^{177}$

It is thus imperative that lower courts, when confronted with patternor-practice claims, refrain from adopting a conceptual framework based on the majority's doctrinal distinction between discrete acts and repeated conduct. According to the Senate Report to the amended Title VII, Congress endorsed a broad construction of the charge-filing provision in Title VII consistent with the goals of eliminating continuing violations. ${ }^{178}$ Specifically, Congress supported the view that courts should interpret the procedural provision broadly so as not to bar certain claims simply because of "procedural oversight" or employees' lack of awareness of the discrimination being perpetrated against them. ${ }^{179}$ Accordingly, lower courts adjudicating pattern-or-practice claims should construe the continuing violation theory broadly, in such a fashion that furthers Title VII's substantive goals.

\section{CONCLUSION}

In National Railroad Passenger Corp. v. Morgan, the United States Supreme Court spoke for the first time on the nature and scope of the continuing violation theory. Specifically, it held that while the procedural doctrine applies to hostile work environment claims, it does not toll or extend the statute of limitations period for claims of discrete discriminatory and retaliatory acts. In the course of its reasoning, the Morgan majority adopted a doctrinal distinction between discrete acts and repeated conduct to justify its holding. Despite the silence of the Morgan majority on pattern-orpractice claims, it is likely that post-Morgan lower courts will adopt a conceptual framework based on the majority's doctrinal distinction when confronted with such claims.

However, an analysis of the Morgan majority's reasoning and the implications of its doctrinal distinction reveals the doctrine's internal incoherence and its failure to take into account the empirical complexities of employment discrimination. Furthermore, adopting this problematic doctrinal distinction for the purpose of determining how to apply the continuing violation theory to pattern-or-practice claims would greatly hinder the ability of pattern-or-practice plaintiffs to pursue their claims successfully. It would thus create obstacles for Title VII's goál of eliminating systemic discrimination and providing make-whole relief. Accordingly, lower courts confronted with pattern-or-practice claims should refrain from adopting such a conceptual framework. They should instead seek to construe Title

176. Griggs v. Duke Power Co., 401 U.S. 424, 429-30 (1971).

177. Albemarle Paper Co. v. Moody, 422 U.S. 405, 418 (1975).

178. See 1972 LEgislative History, supra note 8, at 1846.

179. See id. 
VII's procedural provision and the continuing violation theory broadly, in keeping with Congress's purposes in enacting the statute. 